
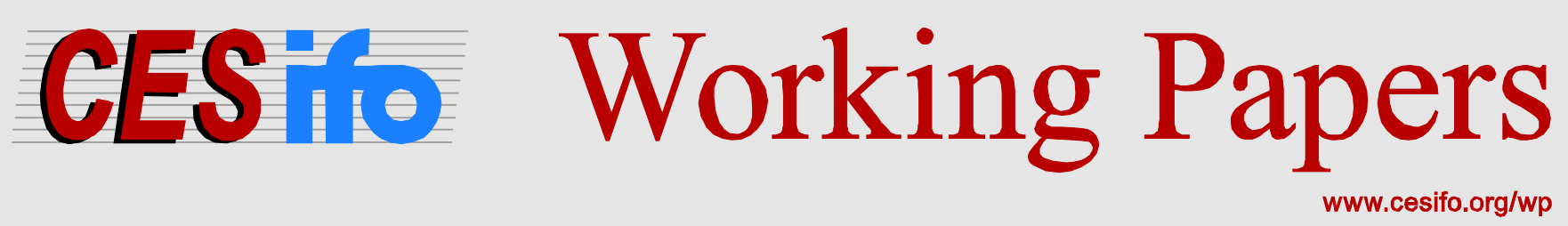

\title{
Children of a (Policy) Revolution: The Introduction of Universal Child Care and its Effect on Fertility
}

\author{
Stefan Bauernschuster \\ Timo Hener \\ Helmut Rainer
}

CESIFO WORKING PAPER NO. 4776

CATEGORY 4: LABOUR MARKETS

APRIL 2014

An electronic version of the paper may be downloaded

- from the SSRN website:

- from the RePEc website:

- from the CESifo website:

WwW.SSRN.com

www.RePEc.org

www.CESifo-group.org/wp

\section{CESifo}




\title{
Children of a (Policy) Revolution: The Introduction of Universal Child Care and its Effect on Fertility
}

\begin{abstract}
What role does affordable and widely available public child care play for fertility? We exploit a major German reform generating large temporal and spatial variation in child care coverage for children under the age of three. Our precise and robust estimates on birth register data reveal that increases in public child care have significant positive effects on fertility. The fertility effects are more pronounced at the intensive than at the extensive margin, and are not driven by tempo effects or selective migration. Our findings inform policy makers concerned about suboptimally low fertility by suggesting that universal early child care holds the promise of being an effective means of increasing birth rates.
\end{abstract}

JEL-Code: J130.

Keywords: public child care, fertility.

\author{
Stefan Bauernschuster \\ Department of Economics \\ University of Passau \\ Innstr. 27 \\ Germany - 94032 Passau \\ stefan.bauernschuster@uni-passau.de
}

\author{
Timo Hener* \\ Ifo Institute - Leibniz Institute for Economic \\ Research at the University of Munich \\ Poschingerstr. 5 \\ Germany - 81679 Munich \\ hener@ifo.de
}

\author{
Helmut Rainer \\ Ifo Institute - Leibniz Institute for Economic Research \\ at the University of Munich \\ Poschingerstr. 5 \\ Germany-81679 Munich \\ rainer@ifo.de
}

*corresponding author

April 17, 2014 


\section{Introduction}

Fertility levels in many developed countries are no longer sufficient to assure the long-term replacement of the population, with predictable economic consequences such as financial difficulties in health care and pensions systems. This raises the question of whether policy makers as agents of the public interest should care about fertility outcomes. Most traditional theories of fertility (see e.g. Leibenstein, 1957; Becker, 1960) assume that the benefits of having an extra child accrue entirely to the parents, and therefore imply that public intervention in individuals' fertility choices cannot be justified other than for equitative purposes. But suppose that the benefit of an extra child does not entirely go to the parents - that children are to some extent a public good and consequently involve positive social externalities. For example, it is well understood that social security schemes in which the active generation pays the pensions of the retired generation socialize part of the benefits of a child, mainly through a growing tax base (see e.g. Cigno, 1993; Folbre, 1994). What we are confronting then is a generalized prisoner's dilemma: fertility choices at the individual level are only based on the direct utility that a couple gets from its offspring, neglecting the fact that progeny benefits all in society. Since this disjunction between private interest and public good implies an insufficient number of children, it has been used by economists as well as demographers to advocate a reexamination of existing public policies and their appropriate redesign in a pronatalist direction (see e.g. Demeny, 1986; Sinn, 2004).

On a theoretical level, there is considerable work exploring approaches to public policy reform that could internalize the positive social externalities associated with offspring (see e.g. Groezen et al., 2003; Fenge and Meier, 2005). On a practical level, some governments have recently responded to concerns about suboptimally low fertility by moving demographic considerations to the top of their political agenda and implementing reforms intended to induce people to have more children (see e.g. Rindfuss et al., 2010; Takayama and Werding, 2011). Chief among these have been efforts to expand public child care. However, there is exceedingly little empirical research on the fertility effects of such policies - especially in the context of countries where fertility has fallen to rates well below the replacement level. As a result, it is still open for debate whether public child care provision is an effective way to increase fertility rates where these rates are considered to be too low.

The aim of this paper is to provide empirical evidence on the relevance of public child care for fertility in Germany. To overcome problems of endogeneity, we draw upon a major German federal reform from the mid-2000s, which led to a large scale staggered expansion of public child care for children under the age of three considerably varying across counties in timing and pace. Germany has long been known for its low fertility, and one of the explicitly stated goals of the reform was to induce couples to have more children by making them less costly in terms of income and career opportunities. In essence, the reform included a commitment by the federal government to move from having almost no child care slots available for children under the age of three to having slots available for all children in this age group. However, although the federal government initiated the reform, local authorities were responsible for the expansion of public child care. This immediately generated large variation in child care coverage, both across time and between West Germany's 325 counties, which we exploit in a difference-in-differences approach as 
well as in a more flexible county-fixed effects specification. Our analysis draws upon birth registration records, which cover all births in West Germany - on average 580,000 annually. We match the information from the birth registers with administrative data on child care coverage at the county-level. The data allows us to examine the effects of public child care both at the extensive margin of fertility (i.e. entry into parenthood) and at the intensive margin (i.e., the number of parents' offspring). Age-specific birth rates allow us to address the timing of births as well as tempo effects. In addition, we are able to ask whether public child care expansion has an effect on babies' health outcomes at birth, which might be expected if such an intervention leads to a change in the composition of parents (Dehejia and Lleras-Muney, 2004).

We present four classes of results. First, we find consistent and robust evidence of a substantial positive effect of public child care expansion on fertility. To be concrete, our estimates suggest that a 10 percentage point increase in public child care coverage increases the number of births per 1,000 women by 1.2 , or roughly $2.8 \%$ of the baseline birth rate. Under the strict assumption of linearity, this result implies that an increase in public child care coverage by 30 percentage points - as ultimately achieved by the reform under consideration - leads the average woman to have roughly 0.12 more children. Given that the total fertility rate in Germany has been hovering around 1.4 for decades, this effect appears to be quantitatively important. Second, we provide evidence that the increase in fertility brought about by public child care expansion is not due to tempo effects, i.e., a tendency towards younger age at birth. Indeed, if anything, our results suggest that the average age of women at birth increases rather than decreases in response to more widely available child care. Third, we find that the effects of public child care on fertility are stronger at the intensive than at the extensive margin, with a 10 percentage point increase in child care coverage increasing the incidence of second and third births by $4 \%$ and $7 \%$, respectively. Fourth, there is no evidence that children born in response to increases in public child care have inferior health outcomes at birth such as a lower birth weight or a lower birth height. A battery of robustness checks, which amongst others deal with regional heterogeneity, selective migration or the timing of the fertility response, corroborate our results. Taken together, our findings contribute to ongoing academic and public debates on family policies and low fertility in developed countries. In particular, our analysis provides some first evidence suggesting that policies that facilitate the combination of parenthood and employment hold the promise of being an effective way to positively influence birth rates where these rates are considered to be too low.

Ever since the seminal works of Leibenstein (1957) and Becker (1960), economists have taken an interest in the analysis of fertility. ${ }^{1}$ However, only a small subset of the existing literature examines the impact of public child care on fertility. From a theoretical perspective, the link between child care and fertility is clear. As affordable child care becomes available, mothers may return to work sooner after childbirth. This, in turn, reduces the opportunity cost of having children - e.g., forgone wages or loss of skill development while out of the labor force - and so increases fertility (see e.g. Becker and Lewis, 1973; Willis, 1973; Ermisch, 2003). However, this theoretical prediction receives weak empirical support; the evidence is mostly descriptive and ambiguous - see, for example, Mason and

\footnotetext{
${ }^{1}$ A substantial part of this literature analyses the negative correlation between income and fertility (see Jones et al. (2010) for a comprehensive review).
} 
Kuhlthau (1992); Del Boca (2002); Hank and Kreyenfeld (2003); Hank et al. (2004); Del Boca et al. (2009); Haan and Wrohlich (2011); Bick (2013). What distinguishes our work from these studies is that we exploit a set of policy reforms which provides us with arguably exogenous variation in the expansion of public child care for under three year old children in a country with very low fertility rates.

To the best of our knowledge, only two other studies exist that use policy reforms to assess the impact of public child care on fertility. ${ }^{2}$ Both studies are conducted within the Scandinavian context, where fertility rates are close to replacement levels. Rindfuss et al. (2010) examine a policy reform from the mid-1970s in Norway, which led to a substantial expansion of public child care. Their results suggest that moving from having no child care slots available for preschool children to having slots available for $60 \%$ of preschool children leads the average woman to have 0.5 more children. Mörk et al. (2013) exploit the exogenous variation in parental fees caused by a Swedish child care reform to identify the effect of child care costs on fertility. The results suggest that the reduction in child care costs increased the number of first and higher order births, but only seemed to affect the timing of second births. The context of our study is Germany, which, unlike Norway and Sweden, is a country already struggling with the ramifications of very low fertility. Thus, our results speak more directly to debates as to whether or not low fertility can be reversed through changes in public policy.

The remainder of the paper is organized as follows. Section 2 gives detailed background information on fertility in Germany and on the policy initiatives that led to a considerable expansion of public child care for under three year olds in West Germany. Section 3 outlines our empirical strategy, and Section 4 describes the data. Section 5 presents the results on the impact of expanding public child care on fertility. In Section 6, we present robustness checks dealing with issues of selective migration and the relevance of tempo effects. Section 7 briefly discusses our findings and concludes.

\section{Background and Context}

Ever since the 1970s, Germany has been among the twenty countries with the lowest fertility rates worldwide (Population Reference Bureau, 2007). Historically, fertility rates in Germany were increasing during the 1950s and early 1960s from just above 2.0 to 2.5 , but they then dramatically decreased in the late 1960s and early 1970 s to a level of 1.5 in 1974. During the last four decades, fertility stayed constant at a very low level

\footnotetext{
${ }^{2}$ There is, however, an impressive amount of research that examines the effects of child care policies on maternal employment. The picture that emerges from this literature in general is that of positive effects from the introduction or expansion of affordable child care on the labor supply of mothers-particularly sole mothers (e.g., Gelbach, 2002; Blau and Tekin, 2007; Baker et al., 2008; Lefebvre and Merrigan, 2008; Cascio, 2009). One notable exception is the study by Havnes and Mogstad (2011a), who exploit the introduction of universal child care in Norway in the late 1970s and find no positive causal relationship between public child care and maternal employment. There are also several studies on the link between child care and child development. On the one hand, there is evidence suggesting both negative (e.g., NICHD - Early Child Care Research Network, 2003a; Baker et al., 2008), neutral (e.g., Lefebvre and Merrigan, 2002) and positive (e.g., NICHD - Early Child Care Research Network, 2004; Havnes and Mogstad, 2011b) effects of the amount of time spent in child care on the developmental outcomes of young children. On the other hand, there appears to be a positive relationship between child care quality and child development (e.g., Field, 1991; NICHD - Early Child Care Research Network, 2003b).
} 
Figure 1: Fertility rate in Germany

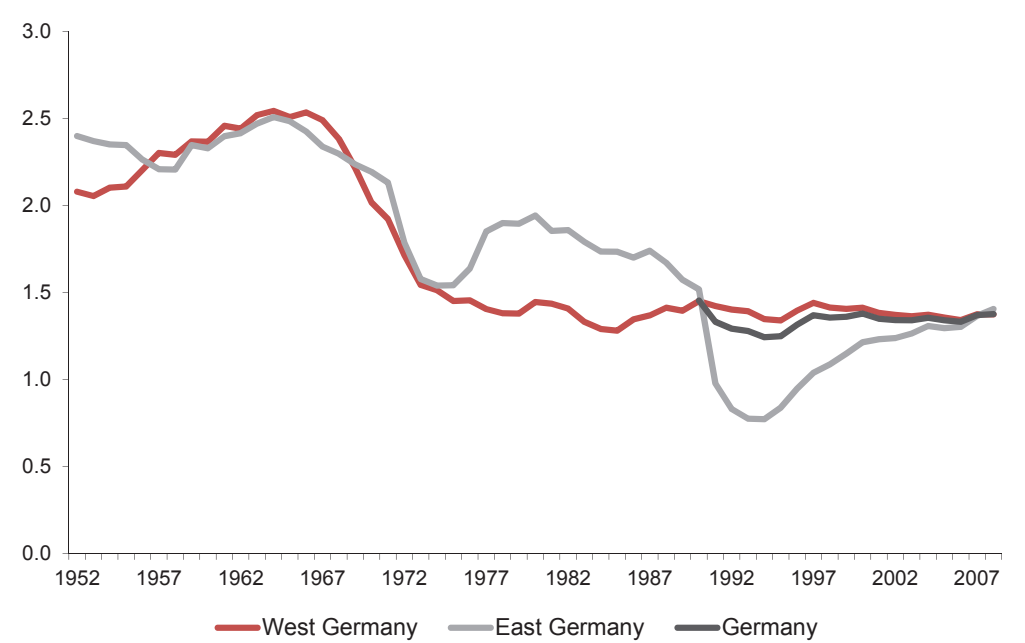

Notes: The figure shows total fertility rates in Germany from 1952 until 2008. Total fertility rates are defined as the average age-specific number of births per woman. It can be interpreted as the total number of children a woman would have, assuming that the age-specific fertility rates of that year stay unchanged throughout the life of a woman. From 2001, data from West Germany do not include West Berlin and data from East Germany do not include East Berlin (German Federal Statistical Office 2009).

of roughly 1.4 (see Figure 1). ${ }^{3}$ Germany's population reached a maximum shortly after the turn of the millennium and has started to decline thereafter as a result of sustained very low fertility rates (Dorbritz, 2008). As a consequence, the German government now approaches demographic issues in an official way and wants to encourage higher fertility through policy interventions, which it refrained from doing after World War II because anything resembling pronatalism was discredited for historical reasons (Takayama and Werding, 2011).

A key initiative in this regard was the introduction of universal public care for children under the age of three. Up until the mid-2000s, the availability of public child care for children in this age group was severely rationed in West Germany. ${ }^{4}$ For example, in a survey conducted in 2005, 35 percent of West German mothers with under three year olds stated a demand for a child care slot (Bien et al., 2006), while only roughly 5 child care slots per 100 children in this age group were available. ${ }^{5,6}$ At the same time, virtually no

\footnotetext{
${ }^{3}$ Data from the World Bank (2009) depict a fertility rate of 1.38 for Germany in 2008. Thus, Germany lies well below the EU-27 average of 1.60 and close to Poland (1.39), Portugal (1.37), Hungary (1.35), or Japan (1.34). Fertility rates in the US (2.10), France (2.00), Norway (1.96), or Sweden (1.91) are substantially higher.

${ }^{4}$ By contrast, in 1996, the German government enacted legislation that granted children aged three to six the right to a place in a public kindergarten. This reform ultimately led to full provision of half-day public child care for children in that age group in West Germany.

${ }^{5}$ Wrohlich (2008) estimates that more than 50 percent of West German mothers with children aged 0-3 were queuing for a child care slot in the mid-2000s, suggesting that the excess demand for child care was even more severe.

${ }^{6}$ The situation was completely different for early child care in East Germany. Throughout the history of the former German Democratic Republic, the East German government strongly supported the use of public daycare for children of all ages. The East German child care system survived the German reunification, with more than one-half of all East German children under the age of three and almost all East German children between three and six attending a child care center in the mid-1990s. At the turn of the millennium, parents in East Germany demanded fewer child care slots for children than were
} 
private market for child care had emerged despite a massive excess demand. ${ }^{7}$ Prompted by the severe rationing of public child care, the German government implemented a set of comprehensive public child care reforms during the period 2005-2008, with the explicit intention to increase fertility levels:

- In 2005, the government made the legal commitment ("Tagesbetreuungsausbaugesetz") to create 230,000 additional child care slots for under three year old children by 2010 in West Germany. The specific aim was a child care coverage rate of $17 \%$ by 2010 in West Germany.

- In 2007, a summit (called "Krippengipfel") of the three federal levels-i.e., federal state, "Länder", local authorities - agreed upon increasing the child care coverage rate for under three year olds to $35 \%$ by 2013.

- In 2008, the law to promote children ( Kinderförderungsgesetz") established the legal claim to a child care slot for all preschool children age one and above by 2013.

The child care slots that were created in response to these initiatives were strongly subsidized, with roughly $80 \%$ of the costs of a slot covered by public subsidies and $20 \%$ covered by parental fees. Although the federal government initiated the reforms, regional authorities (at the county level) had the responsibility to create additional child care slots, which had to satisfy strict quality standards set at the state level. In the run-up to the law the three federal levels agreed that each level bears a share of the expansion costs. Since public child care for under three year olds was virtually non-existent in West Germany before 2005, all counties in each state had to substantially expand public child care in order to be able to fulfill legal claims to a child care slot for all preschool children age one and above by 2013 .

In order to assess the expansion brought about by these initiatives, Figure 2 provides two maps which illustrate the child care coverage rate for West Germany's 326 counties in 2002 and 2009, respectively. In 2002, we observe that the child care coverage rate was consistently below 5\% across virtually all West German counties. In succeeding years, the child care coverage rate more than quintupled to reach an average of $15 \%$ in 2009. However, it is also evident from the map that the counties differ distinctly in the magnitude of public child care expansion. In 2009, the public child care coverage rates vary from $3.7 \%$ to $41.6 \%$. The percentage point increases in child care coverage from 2002 to 2009 range from a minimum of 3 percentage points to a maximum of 27 percentage points. Also note that there is considerable variation in the pace of this expansion across counties even within the same state.

Where does this variation come from? The process of opening up new child care slots involved many complex and intertwined decisions of county level authorities and state level authorities, respectively. On the one hand, authorities at the county level had the

available (Hank et al., 2001). The picture today still is that there is no shortage of child care slots for early children under six in East Germany.

${ }^{7}$ One reason for the lack of a private market are the strict regulations (set at the state-level) faced by child care providers. As pointed out by Felfe and Lalive (2012), these regulations concern dimensions such as opening hours, group sizes, staff-child rations, but also qualifications of the staff before being allowed to work in the sector. 
Figure 2: Public child care coverage in West German counties in 2002 and 2009
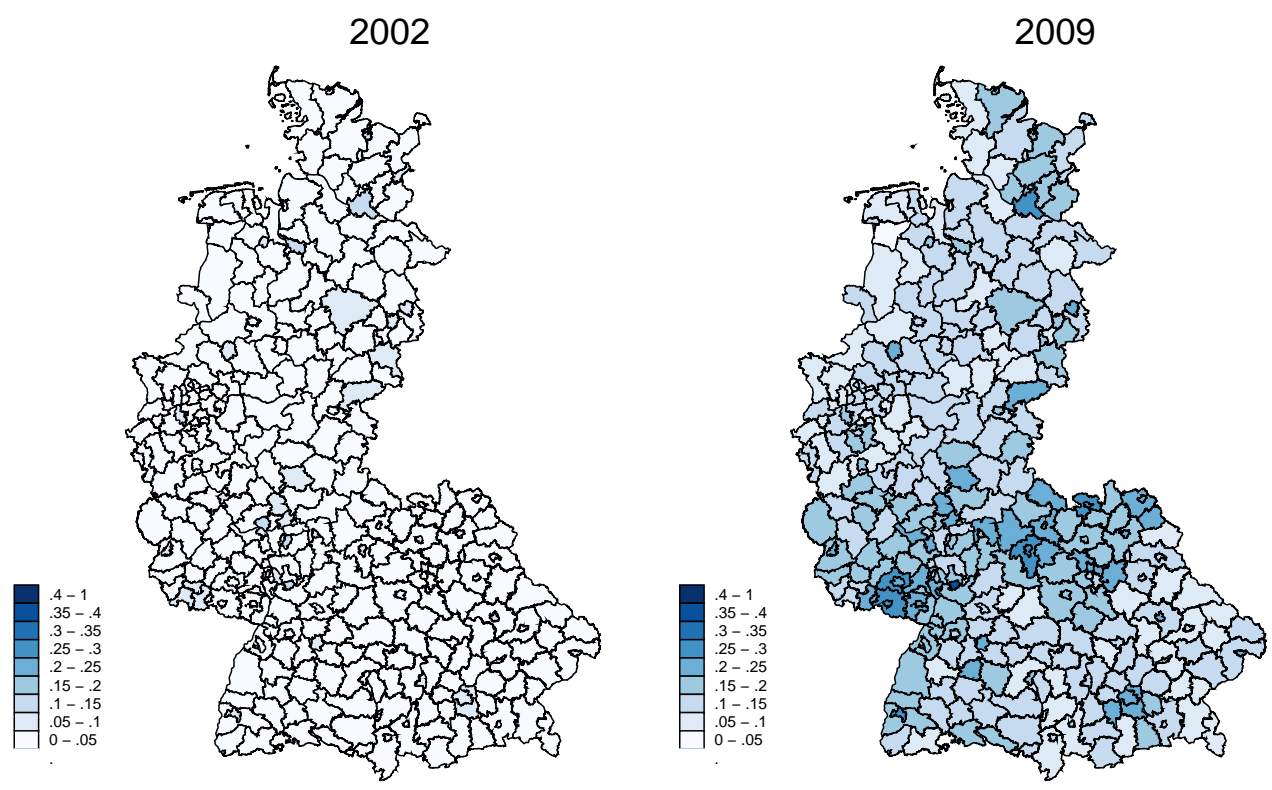

Notes: The left panel shows child care coverage in West German counties in 2002, the right panel shows child care coverage in West German counties in 2009. East German counties are shaded in gray.

responsibility to assess the local demand for child care, with demographic and economic factors such as current cohort sizes and labor market conditions entering the projections. On the other hand, authorities at the state level had to approve proposals to set up new child care centers which were submitted by non-profit organizations. This administrative process was prone to problems that varied substantially across counties and that could not be influenced by local authorities (see e.g. Huesken, 2011; Felfe and Lalive, 2012). Amongst them are varying routines and knowledge about the complicated funding system (with subsidies coming from the federal state, the state and the municipality), shortages in construction ground, various regulations for building child care centers, shortages in qualified child care workers, serious delays in approval or final rejections of applications due to non-compliance with regulations.

\section{Empirical Strategy}

In order to identify the effect of public child care on fertility, we start with a simple difference-in-differences approach which exploits the expansion of public child care for under three year olds during the last decade. In particular, we order the West German counties by the absolute size of the increase in the public child care from 2002 to $2009 .^{8}$

\footnotetext{
${ }^{8}$ We choose the year 2002 as the baseline for two reasons: First, since public child care was not a major political issue until the year 2005, the year 2002 is certainly a year which is unaffected by any political decisions aimed at expanding public child care. Second, the year 2002 is the last year where
} 
Then, we define those counties whose increase in child care coverage was above the median as the treatment group, while those counties whose increase was below the median constitute the control group. By choosing this setting, we follow Havnes and Mogstad (2011a) who use a very similar identification strategy for analyzing the effects of the introduction of universal child care on maternal employment in Norway. The difference-in-differences model should capture the gradual expansion in public child care coverage starting after the policy initiatives in 2005. To this end, we use all years from 1998 to 2009 in the estimation and refer to the period until 2004 as the pre-treatment years. We split the treatment years into two periods to capture heterogeneity in the gradual divergence in child care between the treatment and control group. Thus, we refer to the years from 2005 to 2007 as the Phase I period and to the years from 2008 to 2009 as the Phase II period which is characterized by the largest divergence in child care between the groups.

Accordingly, this difference-in-differences model for the period from 1998 to 2009 can be expressed in the following way:

$$
\begin{aligned}
y_{c t+1}= & \alpha+\beta_{c}+\gamma_{1}\left(\text { Phase }_{t}\right)+\gamma_{2}\left(\text { PhaseI }_{t}\right) \\
& +\delta_{1}\left(D_{c} * \text { Phase }_{t}\right)+\delta_{2}\left(D_{c} * \text { PhaseI }_{t}\right)+X_{c t}^{\prime} \zeta+\epsilon_{c t+1}
\end{aligned}
$$

$y_{c t+1}$ is the number of births by 1,000 women aged 15 to 44 living in county $c$ in year $t+1$. The outcome variable is measured in $t+1$ because there are at least 9 months from the decision to have a child to the actual birth; we will later allow the outcome variable to react to the treatment within an (empirically validated) time frame of up to 22 months. $\beta_{c}$ are county fixed effects and thus capture time-invariant regional heterogeneity. Phase $i n_{t}$ is the indicator for the Phase I years 2005 to 2007, and PhaseII $I_{t}$ is the indicator for the Phase II years 2008 and 2009. Consequently, $\gamma_{1}$ captures differences in fertility between the pre-treatment and the Phase I period that are common to the treatment and control group, while $\gamma_{2}$ captures differences in fertility between the pre-treatment and the Phase II period that are common to the treatment and control group. $D_{c}$ is the treatment group indicator for county $c$, which is unity for counties with above median increase in public child care coverage, and zero for counties with below median increase. The Phase I treatment effect $\delta_{1}$ is identified by the coefficient on the interaction of the treatment group indicator and the Phase I indicator; similarly, the Phase II effect $\delta_{2}$ is identified by the coefficient on the interaction of the treatment group indicator and the Phase II indicator. ${ }^{9} X_{c t}$ is a vector of time-varying county-specific covariates. Standard errors $\epsilon$ are clustered on the county level. ${ }^{10}$

Note that in this reduced form difference-in-differences regression, the treatment ef-

administrative data on child care coverage at the county level is available before it became a political issue in 2005. Data exists for the years 1998, 2002 and 2006-2009.

${ }^{9}$ Note that the financial crisis had mild effects in Germany by international standards. Still, if the intensity of the financial crisis varied by treatment and control group counties and is at the same time correlated with fertility, this might affect the Phase II effect but not the pre-crisis Phase I effect. Instead of using two phases, we also experimented with year-by-year interactions with the treatment group indicator, which did not affect our findings.

${ }^{10}$ We also ran regressions using nonparametric cluster bootstrap standard errors (Mooney and Duval, 1993) using pairs resampling with county clusters; see Cameron et al. (2008) for a discussion of bootstrap methods. Our results are qualitatively unchanged. Cluster bootstrap standard errors are even slightly smaller than the cluster-robust standard errors reported in the paper. 
fects $\delta_{1}$ and $\delta_{2}$ are best interpreted as intention-to-treat effects (ITT). In order to make statements about the average treatment effects on the treated (ATT), we have to rescale these reduced form estimates by the emerging difference in child care coverage between treatment and control group counties. This rescaled parameters can then be interpreted as the effect of public child care coverage on fertility (see also Baker, Gruber and Milligan 2008 or Havnes and Mogstad 2011).

The key identifying assumption for this difference-in-differences model is that treatment and control group follow the same fertility trend in absence of the treatment. Since we control for county fixed effects, the expansion of public child care need not be orthogonal to county characteristics. It is nevertheless informative to investigate differences in pre-treatment characteristics between treatment and control group counties. As we will show in detail below, treatment and control group counties are indeed very similar in their pre-treatment characteristics.

Even if counties are very similar in their pre-treatment characteristics, it might be the case that time-varying factors which are correlated with fertility evolve differently in the treatment group as compared to the control group counties and thus bias the estimates. To address this concern, we run a placebo treatment test to show that treatment and control group follow the same fertility trend in the pre-treatment period. Of course, even if the trends are very similar prior to the treatment, this does not safeguard us against the possibility that they deviate from each other in the Phase I and Phase II years for reasons other than the expansion of public child care. Thus, to further investigate the robustness of our results with respect to time-varying county characteristics, we run the differencein-differences regression both without any covariates and with a rich set of county-specific time-varying covariates.

Let us briefly outline the basic intuition behind the choice of the time-varying covariates in our empirical analysis. Note that one potential confounding factor could be changes in predicted fertility at the local level. As we have argued above, virtually all West German counties had to massively expand public child care in response to the federal child care initiatives. However, it is conceivable that the pace of expansion is affected by changes in predicted fertility within a county over time. In other words, although predicted child care demand exceeds current supply in virtually all counties, the political pressure to quickly increase child care supply might be higher in counties where predicted increases in fertility (or closely related, future increases in child care demand) is relatively high, which would bias the estimates upwards. To minimize this problem, we control for time-varying local socio-demographic factors which are typically used to predict fertility, and therefore also might be relevant for local authorities, in all regressions. In particular, we include extremely detailed information on a county's population age structure to capture local demographics. These are year of age specific population shares of females aged 15 to 44 and of the whole population aged 45 and above. Furthermore, we control for the population density to account for regional agglomeration tendencies, and the male employment rate to capture local labor market conditions. By controlling for GDP per capita we capture a county's prosperity and mitigate effects of the financial crisis that may affect counties differentially. Moreover, we directly control for local political attitudes by including the conservative vote share as an additional covariate. ${ }^{11}$ In extended

\footnotetext{
${ }^{11}$ All other major parties including the FDP are associated with more liberal family policies. We also
} 
regressions, we also include municipalities' gross revenue and debt to capture time-varying differences in local public finance, which may be important in the decisions to expand child care. Furthermore, we include the number of newly built dwellings which may be geared towards attracting families. Given the range of county specific administrative difficulties mentioned in Section 3, and conditional on the extensive set of local covariates, it seems plausible to assume that the variation in the pace of the mid- to late-2000s child care expansion was exogenous to future changes in fertility.

As to other reforms that may induce confounding variation, the federal government introduced a parental leave reform in 2007, which essentially decreased the duration of parental leave benefits from 24 to 12 months while increasing the amount of the benefit. Since this federal reform applied to all German counties at the same time, it should not confound the estimates as long as the effects of the reform do not systematically vary between counties of the treatment group and counties of the control group. Apart from the parental leave reform, we are not aware of any other policy intervention which might have affected fertility.

To make sure that the estimates are not contingent on the exact definition of the treatment group counties, we test whether the results are robust if we redefine treatment and control group. In particular, we use the top $40 \%$ in terms of child care expansion as the treatment group counties and the lowest $40 \%$ in terms of child care expansion as the control group counties, leaving out the middle 20 percentiles. Moreover, to avoid any problems with the definition of treatment and control group, we use a more generalized fixed-effects framework for the period from 1998 to 2009 which can be written in the following way:

$$
y_{c t+1}=\eta_{c}+\mu_{t}+X_{c t}^{\prime} \lambda+\rho d_{c t}+\zeta_{c t+1}
$$

where $\eta_{c}$ is a county fixed effect for county $c$ and thus captures time-invariant heterogeneity between counties, $\mu_{t}$ is a fixed effect for year $t$, and $X_{c t}^{\prime}$ is a vector of covariates of county $c$ that vary over time $t$. The key variable of interest $d_{c t}$ represents the public child care coverage rate of county $c$ in year $t$. Accordingly, $\rho$ captures the effect of public child care coverage on fertility. As before, $y_{c t+1}$ is the outcome variable measuring the number of births per 1,000 women aged 15 to 44 living in county $c$ in period $t+1$. Standard errors $\zeta$ are allowed to correlate within counties over time. In this fixed-effects specification, identification comes from within-county variation in public child care coverage over time. Note that by using this specification, we restrict the marginal effects of expansions in public child care coverage to be constant. Furthermore, in contrast to the reduced form difference-in-differences specification, we can only use the years $t$ for which we actually observe public child care coverage in the data.

Analogous to the difference-in-differences specification, the key identifying assumption in the fixed effects framework is that conditional on the extensive set of covariates there are no unobserved characteristics of a county that vary over time and are correlated with public child care expansion and future changes in fertility.

experimented with vote shares for all parties and did not find the results to be affected. 
Table 1: Child care coverage over time

\begin{tabular}{ccccccc}
\hline \multicolumn{7}{c}{ Child care coverage } \\
Year & $\mathrm{N}$ & Mean & Median & S.D. & Min & Max \\
\hline 1998 & 325 & 0.017 & 0.009 & 0.020 & 0.000 & 0.117 \\
2002 & 325 & 0.022 & 0.015 & 0.023 & 0.000 & 0.131 \\
2006 & 325 & 0.073 & 0.068 & 0.038 & 0.010 & 0.233 \\
2007 & 325 & 0.094 & 0.085 & 0.044 & 0.022 & 0.289 \\
2008 & 325 & 0.117 & 0.109 & 0.048 & 0.033 & 0.352 \\
2009 & 325 & 0.142 & 0.135 & 0.050 & 0.037 & 0.359 \\
\hline Total & 1950 & 0.077 & 0.071 & 0.061 & 0.000 & 0.359 \\
\hline Notes: The figures show mean child care coverage rates across \\
West German counties as well as standard deviations, median, \\
minimum, and maximum values. All information is provided for \\
the years 1998, 2002, 2006, 2007, 2008, and 2009.
\end{tabular}

\section{Data}

We use administrative data from the Statistical Offices of the German Länder (Statistische Landesämter) on public child care for children under the age of three. This data is available for the years 1998, 2002, 2006, 2007, 2008, and 2009. The number of public child care slots are reported to the authorities in the first half of March in every year. Combining these data with detailed administrative data on the counties' population structure, we build the key variable of interest, public child care coverage, defined as public child care slots over the population of children less than three years old, which we also simply refer to as child care in the following. Table 1 shows that public child care coverage averages $7.7 \%$ over the whole period of observation and varies widely from 0 to 35.9\%. Average coverage rates across West Germany's 325 counties was very low in $1998(1.7 \%)$ and 2002 $(2.2 \%)$. The modest increase from 1998 to 2002 is mainly explained by a decrease in births rather than an increase in child care slots (DJI, 2005). Yet, there is already some variation across counties with some reporting no child care for under three year olds at all and other counties reporting coverage rates up to $13.1 \%$. After 2005, the reform takes effect and the rise in coverage rates accelerates. In 2006, the rates reach $7.3 \%$ on average. The minimum value is lifted above zero and the maximum value up to $23.3 \%$. Until 2009, the average coverage is doubled to a value of $14.2 \%$. Note that while the whole distribution of child care coverage shifted to the right, we do not observe a convergence process between counties; rather, the standard deviation of coverage rates steadily increases from 1998 to 2009. Closer inspection of the data reveals that patterns of child care expansion are very heterogenous across counties. Some counties expand very slowly and others very fast; some counties gradually increase child care over time, other counties start off strong but come to a halt, again other counties are delayed by a couple of years and later increase coverage steeply. Overall, we find many different types of expansion patterns (see Figures A.1 and A.2 in the Appendix).

Register data based on the universe of birth certificates of all 325 West German coun- 
ties $^{12}$, covering roughly 580,000 births per year, are the basis of our fertility measures. We collapse the individual birth data on county-year cells for the period from 1998 to 2010 . At the county level, the data is combined with the administrative data on the population structure to compute fertility outcome variables. The main dependent variable births per 1,000 women is calculated as the sum of births over 1,000 women in reproductive age, i.e., between 15 and 44 years. We refer to this outcome variable as birth rate in the following. Additionally, the data also allow us to compute disaggregated age-specific birth rates, i.e., the number of births per 1,000 women of a specific age over 1,000 women of this specific age. The denominators of these fertility measures make sure that the results are not confounded by changes in the size of the relevant female population. For births within a given marriage, we know whether the birth is the first, second, third, fourth or higher-order birth which allows us to analyse the effects of the child care expansion at the extensive and intensive margin. Moreover, we draw on complementary information on children's birth weight and birth height, which is available for all births in the data set.

We measure births in year $t$, i.e., in the same year as the independent variables, and in year $t+1$. The reason is that the main variable of interest, child care, is measured in the first half of March each year, while births (as the sum of births in a year) are measured on 31st December. By allowing fertility to respond in $t$ and in $t+1$, we allow for a conception and gestation lag of a maximum of 22 months. The suitability of this timing specification will later also be validated empirically. As can be seen from Table 2 , birth rates in $t$ average at 44.2, with a standard deviation of 4.4. Figures range from 28 in the lowest fertility county-year observation to 64 in the highest fertility county-year observation. For birth rates in $t+1$, figures are very similar with an average of 44.1. Age-specific fertility rates differ substantially as is evident from Figure 3. In particular, we find an inverted $\mathrm{u}$-shape relation between birth rates and age peaking at around 30. Aggregating this information into age groups, we observe almost 90 births per 1,000 women aged 25-29 or 30-34, whereas the respective numbers for other age groups are considerably lower (Table 2 ). This means that changes in the composition within the population of 15 to 44 year old women affect the main outcome variable, births over 1,000 women in reproductive age. Therefore, we include the share of women aged 15, 16, 17, 18, .., 44 in all women aged 15-44 within a county in our regressions in order to receive results that are not biased by compositional changes. For reasons of clarity we only report a condensed female age structure in Table 2. The detailed year-of-age controls that we use in our regressions are depicted in Table A.1. The share of younger cohorts in the population of females aged 15 to 44 is typically smaller than the share of older cohorts in our period of observation (see Table 2), which is a result of the substantial fertility decline in the mid-1960s.

Further data from the Statistical Offices of the German Laender (Statistische Landesämter) and the Federal Employment Agency (Bundesagentur für Arbeit) complement the county level panel data set. Descriptive statistics of all available variables are presented in Table 2. Counties differ substantially in population density, defined as total population divided by surface area in square kilometers, with values ranging from 40 to over 4,000 people per square kilometer; on average, the population density amounts to 566 people per square kilometer. GDP per capita averages at $28,040 €$, ranging from $11,000 €$

\footnotetext{
${ }^{12}$ Data is provided by the Statistical Offices of the German Laender (Statistische Landesämter).
} 
Table 2: Descriptive statistics

\begin{tabular}{|c|c|c|c|c|c|}
\hline Variable & $\mathrm{N}$ & Mean & S.D. & Min & Max \\
\hline \multicolumn{6}{|l|}{ Dependent variables } \\
\hline Birth rate of women $15-44(\mathrm{t})$ & 1,950 & 44.150 & 4.409 & 27.942 & 63.944 \\
\hline Birth rate of women $15-44(\mathrm{t}+1)$ & 1,950 & 44.106 & 3.984 & 29.860 & 65.440 \\
\hline Birth rate of women $15-19(t+1)$ & 1,950 & 9.766 & 4.288 & 0.911 & 36.554 \\
\hline Birth rate of women $20-24(t+1)$ & 1,950 & 45.922 & 12.567 & 10.937 & 90.206 \\
\hline Birth rate of women 25-29 (t+1) & 1,950 & 89.826 & 14.865 & 34.563 & 134.450 \\
\hline Birth rate of women $30-34(t+1)$ & 1,950 & 89.115 & 11.187 & 54.850 & 121.518 \\
\hline Birth rate of women 35-39 $(\mathrm{t}+1)$ & 1,950 & 39.766 & 9.030 & 16.555 & 78.115 \\
\hline Birth rate of women $40-44(t+1)$ & 1,950 & 6.646 & 2.279 & 0.984 & 18.042 \\
\hline \multicolumn{6}{|l|}{ Control variables } \\
\hline Population density & 1,950 & 565.614 & 690.240 & 40.720 & 4286.211 \\
\hline Employment rate $(\mathrm{m})$ & 1,950 & 0.604 & 0.059 & 0.406 & 0.737 \\
\hline GDP per capita (in 1,000$)$ & 1,950 & 28.040 & 10.812 & 11.238 & 86.079 \\
\hline Conservative vote share & 1,950 & 0.392 & 0.093 & 0.195 & 0.750 \\
\hline Gov revenue & 1,610 & 383.213 & 452.072 & 56.630 & 5775.025 \\
\hline Gov & 1,932 & 0.214 & 0.279 & 0.000 & 3.335 \\
\hline New $c$ & 1,950 & 0.583 & 0.639 & 0.008 & 14.536 \\
\hline n $15-19$ & 1,950 & 0.145 & 0.020 & 0.084 & 0.186 \\
\hline Share of women $20-24$ & 1,950 & 0.144 & 0.020 & 0.107 & 0.272 \\
\hline Share of women $25-29$ & 1,950 & 0.149 & 0.019 & 0.114 & 0.223 \\
\hline Share of women $30-34$ & 1,950 & 0.161 & 0.025 & 0.121 & 0.232 \\
\hline Share of women 35-39 & 1,950 & 0.192 & 0.017 & 0.109 & 0.250 \\
\hline Share of women $40-44$ & 1,950 & 0.211 & 0.024 & 0.137 & 0.276 \\
\hline Population fraction $45-49$ & 1,950 & 0.078 & 0.008 & 0.057 & 0.095 \\
\hline Population fraction $50-54$ & 1,950 & 0.067 & 0.007 & 0.041 & 0.085 \\
\hline Population fraction $55-60$ & 1,950 & 0.062 & 0.007 & 0.038 & 0.090 \\
\hline Population fraction $60-64$ & 1,950 & 0.056 & 0.008 & 0.036 & 0.081 \\
\hline Population fraction $65-69$ & 1,950 & 0.058 & 0.008 & 0.036 & 0.081 \\
\hline Population fraction $70-74$ & 1,950 & 0.049 & 0.007 & 0.031 & 0.072 \\
\hline $\begin{array}{l}\text { Population fraction } 75+ \\
\text { Detailed population structur }\end{array}$ & 1,950 & 0.082 & 0.014 & 0.040 & 0.127 \\
\hline \multicolumn{6}{|l|}{ Robustness dependent variables } \\
\hline In-migrants $18-29$, fem., $(\mathrm{t}+1)$ & 1,625 & 0.009 & 0.005 & 0.003 & 0.049 \\
\hline In-migrants $18-49$, fem., $(\mathrm{t}+1)$ & 1,625 & 0.014 & 0.007 & 0.006 & 0.096 \\
\hline Out-migrants $18-29$, fem., $(t+1)$ & 1,625 & 0.008 & 0.003 & 0.004 & 0.047 \\
\hline Out-migrants $18-49$, fem., $(\mathrm{t}+1)$ & 1,625 & 0.014 & 0.005 & 0.006 & 0.095 \\
\hline Commuter (out), fem., (t+1) & 1,747 & 0.053 & 0.023 & 0.011 & 0.126 \\
\hline Commuter (out), mal., $(\mathrm{t}+1)$ & 1,747 & 0.084 & 0.031 & 0.021 & 0.175 \\
\hline
\end{tabular}

Notes: The table shows descriptive statistics (number of obser minimum, and maximum) on the county level aggregated over all waves used in the estimations. Birth rates are births per 1,000 women in the respective age bracket. The figures show aggregated values over the years 1998, 2002, 2006, 2007, 2008, and 2009. Accordingly, all variables measured in $(\mathrm{t}+1)$ are aggregated over the years 1999, 2003, 2007, 2008, 2009, and 2010. Debt and revenue of municipalities are not reported for the federal city states Hamburg and Bremen (including Bremerhaven). Revenue information is missing in 2001 from all 15 Schleswig-Holstein counties. Revenue information in 2009 is not included due to fragmentary raw data. Revenue and debt figures are divided by 1,000,000 EUR and the number of new dwellings is divided by $1,000 .{ }^{1}$ Tables of descriptive statistics for share of females and the population by years of age as used as control variables can be found in the Appendix. 
Figure 3: Age-specific birth rates

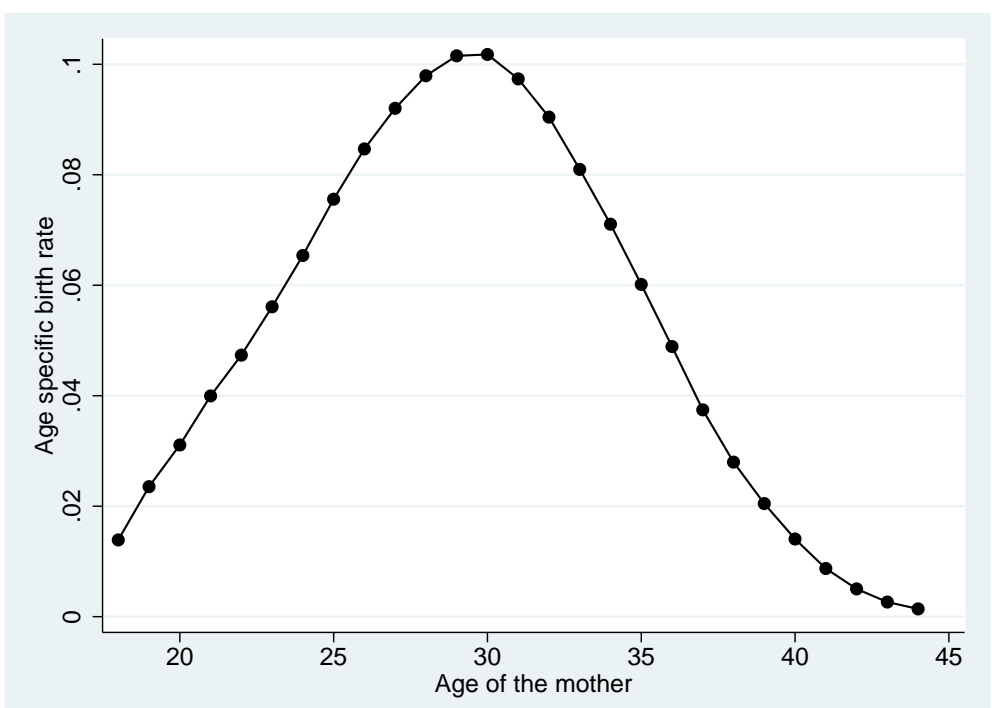

Notes: The figure shows year-of-age specific birth rates as births per 1,000 of the respective age averaged over all counties and years used in the estimations.

to $86,000 €$. The male employment rate is defined as the total number of male employees subject to social insurance contribution at place of residence divided by male working age population (20 to 64 year olds) and averages at $60.4 \%$ with a standard deviation of 0.06 . The lowest observed male employment rate is $40.6 \%$, while the highest one is $73.7 \%$. We also use information on population shares of 45 year olds, 46 year olds, 47 year olds, ..., 74 year olds, and 75 and older individuals. For clarity of exposition Table 2 shows only condensed statistics of the actual year-of-age controls which are presented in detail in Table A.2. Furthermore, we include the vote share of the conservative party $\mathrm{CDU} / \mathrm{CSU}$. In particular, we draw upon the variable as the vote share of the conservative party in the last general elections and interpolate the years between elections by county. The conservative vote share averages at $39.2 \%$ in our sample ranging from $19.5 \%$ to $75 \%$.

In robustness checks dealing with potential selective migration, we use female gross migration flows in $t+1$ divided by a county's total population in $t$ as dependent variables. This variable is not available for the year 1998, which reduces the sample size by 325 observations. The numbers indicate that women migrating across county boarders represent about $1.4 \%$ of the population. We also use the male and female commuters as a share of the total population in further robustness checks. On average, female commuters account for $5.3 \%$ and male commuters for $8.4 \%$ of a county's population. A detailed description of the data and variable definitions can be found in the Data Appendix.

\section{Results}

\subsection{Descriptives}

We start our empirical analysis by comparing pre-treatment characteristics of West German counties with an above-median increase in child care (treatment group) and a belowmedian increase in child care (control group), respectively. Table 3 depicts the means as 
well as the results of t-tests for differences in means of baseline characteristics for the two groups in the pre-treatment year 2002. The statistics show that child care coverage is not statistically different between the groups prior to the treatment, whereas the birth rate is significantly lower in the treatment group. This means that it was not the high but rather the low fertility counties that substantially expanded the supply of child care slots in response to the federal policy initiative. Interestingly, treatment and control group are statistically indistinguishable along a number of fundamental determinants of local birth rates and public child care. These include county measures such as the population density, GDP per capita, the male employment rate, the conservative vote share, municipalities' gross revenue and debts, and the number of new dwellings. Coming to pre-treatment differences in the age structure of the population, we have aggregated the age specific values to age groups to provide a short overview in Table $3 .{ }^{13}$ We observe that treatment and control group counties only marginally differ from each other in the population's age structure. In the most relevant age range for fertility from 20 to 34, differences are not statistically significant. ${ }^{14}$ In cases where the difference turns out to be significant, the absolute and relative sizes of the differences are very small. Thus, the general picture we get from Table 3 supports our argument that the expansion of child care did not happen in a predictable and systematic way, but was subject to unintentional delays. Nevertheless, we will use county fixed effects in all our regressions and show that the inclusion of all observable time-varying county characteristics as controls does not affect the results.

Let us now turn to Figure 4 which shows the development of child care and fertility for the treatment and control group counties over time. As we can see from panel (i) of Figure 4, child care for under three year olds was virtually non-existent in 1998 with coverage rates of not even $2 \%$ for both groups of counties. From 1998 to 2002, we observe hardly any dynamics; the slight rise in coverage rates is due to a decreasing number of births rather than an increasing number of child care slots. As outlined in Section 3, the federal initiatives to increase child care started in 2005. Unfortunately, there are no administrative data available for child care in the period from 2003 to 2005. By 2006, coverage rates had increased from a mere $2 \%$ to $5 \%$ in the control group and to $9 \%$ in the treatment group. In 2010, coverage was already $21 \%$ in treatment counties and $14 \%$ in control counties. Thus, while treatment and control group counties started out from the same low level of child care in 2002, trends diverged in the following years and the difference in the coverage rates reached more than 7 percentage points in 2010. Panel (ii) of Figure 4 depicts this increase in the difference between treatment and control counties. Again, note that we do not have data on child care for the years 2003 to 2005 . Consequently, the graph should not be misinterpreted as a piece of evidence for a starting divergence in child care trends already before 2006.

Turning to panel (iii) of Figure 4, we see that the treatment group counties show lower birth rates than the control group counties over the whole period of observation. For both treatment and control group counties, the birth rates generally decreased from 1998 (49.1; 50.9) until 2006 (41.0; 42.7) whereas there is a slight upward movement from 2006 until $2010(43.3 ; 44.5)$. The graph provides first suggestive evidence that treatment and control

\footnotetext{
${ }^{13}$ The differences in means of the detailed age specific variables can be found in Tables A.3 and A.4 in the Appendix.

${ }^{14}$ This is also true for the year of age controls used in the estimation as depicted in Table A.3.
} 
Table 3: Pre-treatment descriptives for treatment and control group

\begin{tabular}{|c|c|c|c|c|c|}
\hline \multirow[t]{2}{*}{ Variable } & \multicolumn{2}{|c|}{ Mean } & \multirow{2}{*}{$\begin{array}{l}\text { Mean-Diff. } \\
(\mathrm{T}-\mathrm{C})\end{array}$} & \multicolumn{2}{|c|}{ T-test } \\
\hline & Control & Treatment & & t-stat & p-value \\
\hline \multicolumn{6}{|l|}{ Child care } \\
\hline Child care coverage & 0.020 & 0.024 & 0.004 & -1.681 & 0.094 \\
\hline \multicolumn{6}{|l|}{ Dependent variables } \\
\hline Birth rate $(\mathrm{t})$ & 45.682 & 43.671 & -2.011 & 5.272 & 0.000 \\
\hline Birth rate $(t+1)$ & 44.798 & 42.686 & -2.112 & 5.788 & 0.000 \\
\hline \multicolumn{6}{|l|}{ Control variables } \\
\hline Population density & 591.161 & 540.916 & -50.245 & 0.658 & 0.511 \\
\hline Employment rate (m) & 0.604 & 0.600 & -0.004 & 0.663 & 0.508 \\
\hline GDP per capita (in 1,000$)$ & 25.376 & 26.956 & 1.580 & -1.433 & 0.153 \\
\hline Conservative vote share & 0.439 & 0.447 & 0.009 & -0.623 & 0.534 \\
\hline Gov income & 358.914 & 358.051 & -0.863 & 0.019 & 0.985 \\
\hline Gov debt & 0.220 & 0.214 & -0.006 & 0.201 & 0.841 \\
\hline New dwellings & 0.668 & 0.635 & -0.033 & 0.601 & 0.548 \\
\hline Share of women $15-19$ & 0.138 & 0.132 & -0.006 & 3.517 & 0.000 \\
\hline Share of women $20-24$ & 0.139 & 0.140 & 0.001 & -0.726 & 0.468 \\
\hline Share of women $25-29$ & 0.136 & 0.136 & 0.001 & -0.363 & 0.717 \\
\hline Share of women $30-34$ & 0.179 & 0.179 & 0.000 & 0.174 & 0.862 \\
\hline Share of women 35-39 & 0.210 & 0.213 & 0.003 & -2.255 & 0.025 \\
\hline Share of women $40-44$ & 0.199 & 0.200 & 0.001 & -0.998 & 0.319 \\
\hline Population fraction $45-49$ & 0.070 & 0.071 & 0.001 & -2.803 & 0.005 \\
\hline Population fraction $50-54$ & 0.064 & 0.065 & 0.001 & -2.033 & 0.043 \\
\hline Population fraction $55-60$ & 0.053 & 0.052 & 0.000 & 0.412 & 0.680 \\
\hline Population fraction $60-64$ & 0.067 & 0.066 & 0.000 & 0.642 & 0.521 \\
\hline Population fraction $65-69$ & 0.055 & 0.055 & -0.001 & 1.792 & 0.074 \\
\hline Population fraction $70-74$ & 0.044 & 0.043 & -0.001 & 2.138 & 0.033 \\
\hline $\begin{array}{l}\text { Population fraction } 75+ \\
\text { Detailed population structure }^{1}\end{array}$ & 0.073 & 0.070 & -0.003 & 2.185 & 0.030 \\
\hline \multicolumn{6}{|c|}{$\begin{array}{l}\text { Detalled population structure } \\
\text { es: The table shows means, differences in means and differences-in-means-tests for the control and }\end{array}$} \\
\hline
\end{tabular}

group counties indeed follow a common fertility trend in the pre-treatment years, whereas we observe a slight departure from the common trend after 2005 as the treatment group slowly approaches the control group level. Normalizing the difference in birth rates in 1999 to zero, panel (iv) of Figure 4 focuses on the dynamics of this difference over time. As can be seen, the difference in fertility between treatment and control group does not systematically change from 1998 until 2004. However, the birth rates in the treatment group gradually increase as compared to the birth rates in the control group starting in 2005, which is exactly the year of the first federal policy initiative aimed at making child care more widely available. By 2010, the birth rates increased by 0.86 births more in the treatment group than in the control group. Thus, taken together, these graphs are compatible with the hypothesis that fertility increases with the provision of child care.

\subsection{Difference-in-differences results}

In a next step, we bring the descriptive graphs to a multivariate difference-in-differences framework. Recall that the years from 1998 to 2004 form the pre-treatment years, the years from 2005 to 2007 form the Phase I years, and the years from 2008 to 2009 are 
Figure 4: Child care and fertility in treatment and control group

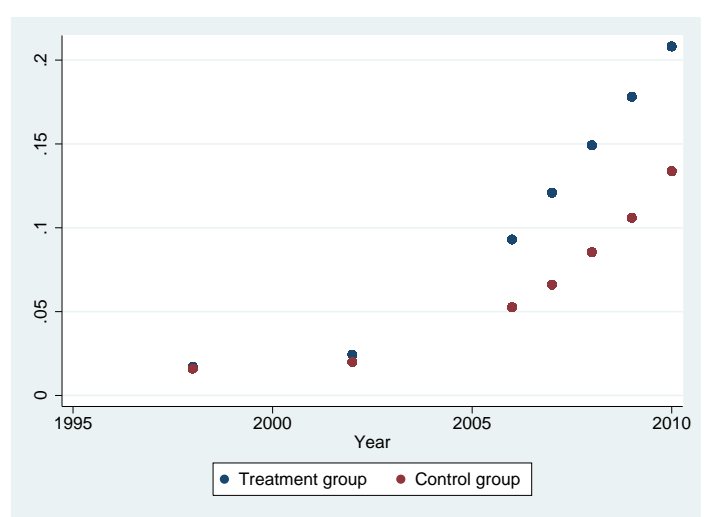

(i) Child care

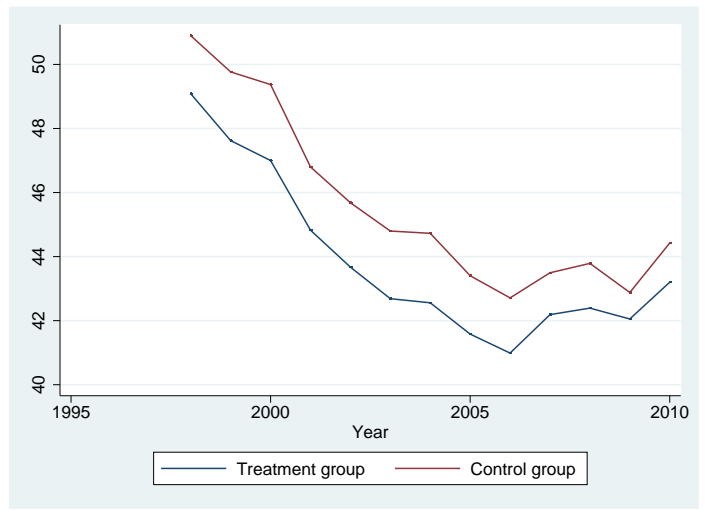

(iii) Fertility

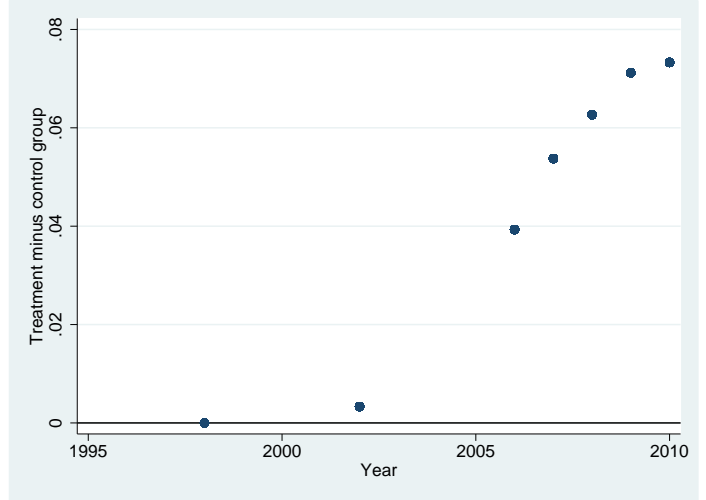

(ii) Child care

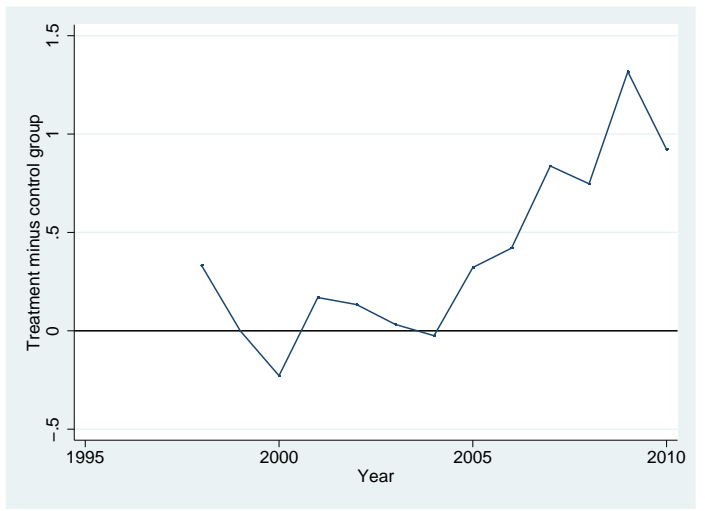

(iv) Fertility

Notes: The figures show averages of the treatment group $(\mathrm{D}=1)$ and the control group $(\mathrm{D}=0)$ and the difference between the treatment and the control group $((D=1)-(D=0))$ over time. The treatment group consists of all counties with above median increase in child care coverage rates from 2002 until 2009, whereas the control group consists of counties with below median increase in child care coverage rates from 2002 until 2009. The figure in panel (i) depicts child care coverage over time, separately for treatment and control group. The figure in panel (ii) depicts the difference between the treatment and the control group in child care coverage over time. The figure in panel (iii) depicts birth rates over time, separately for treatment and control group. The figure in panel (iv) depicts the difference between the treatment and the control group in birth rates over time, normalized to zero in 1999.

the Phase II years. Our first set of results is displayed in panel (i) of Table 4. Using birth rates in $t$ as the outcome variable, we find positive and significant ITT effects which increase from the Phase I to the Phase II period. Compared to the control group, the birth rate in the treatment group increased by 0.467 more from the pre-treatment to the Phase I years, and by 0.973 more from the pre-treatment to the Phase II period (column 1). Next, we include an extensive set of 65 regional covariates in addition to the 325 county fixed effects into the difference-in-differences regression (column 2). In particular, we control for age specific shares in the subsample of women aged 15 to 44 as well as age specific shares of 45 year olds and older in the total population to capture emerging differences in the population age structure that might affect fertility. Furthermore, we capture changes in regional agglomeration by including the county's population density. To control for changes in regional labor markets, we use the male employment rate as an additional covariate. GDP per capita is used to control for changes in regional prosperity. Finally, we include the conservative vote share to capture changes in political attitudes 
of a county's population. As we can see from the table, our results are robust to the inclusion of all these control variables. We still find positive and significant ITT effects which grow over time. The ITT estimates can be interpreted as treatment effects on the treated (ATT) if we rescale them by the emerging difference in child care between treatment and control group in the respective years. Our estimates suggest that a 10 percentage point increase in child care increases birth rates by about 1.0 births in the Phase I period and by 1.3 in the Phase II period. As the effect sizes from the different periods are quite similar, we cannot rule out that the effect of child care on birth rates is linear. In terms of relative size, the estimates correspond to an increase in birth rates of $2.3 \%$ and $3.0 \%$, respectively. ${ }^{15}$

Remember that child care is measured in the first half of March in every year while the birth rate covers the period from 1st of January until 31st of December of the respective year. Individuals might not be immediately aware of increases in local coverage rates. Further, even if individuals are aware, they might not react immediately to changes in child care provision. Moreover, even if they do, women might not be successful in getting pregnant within a short period. Therefore, we forward the outcome variable by one year to allow for a conception and gestation lag of up to 22 months after child care is observed, which is also in line with the literature on fertility responses to public policies (see e.g. Rindfuss et al., 2010). In column 3 of Table 4, we estimate the effect of child care in year $t$ on birth rates in year $t+1$. The estimated ITT effects are slightly larger in year $t+1$ than in year $t$; yet, they are not significantly different from each other. Including the extensive set of regional covariates in column 4 of Table 4 does again not change the results. Accordingly, the corresponding ATTs also show very similar results for births in $t+1$ as for births in $t$.

The key identifying assumption of the difference-in-differences approach is that the fertility trends are the same for treatment and control group in absence of the treatment. In order to provide evidence for the plausibility of this assumption, we run placebo treatment difference-in-differences estimations in the pre-treatment years. In particular, we use the years from 1998 until 2001 as the baseline period and the years from 2002 to 2004 as the placebo period. Panel (iii) of Table 4 presents the results of this placebo treatment test. We find no divergence from a common trend during the pre-treatment years, irrespective of whether we look at births in t (columns 1 and 2) or births in t+1 (columns 3 and 4), or whether we estimate the model without any covariates (columns 1 and 3) or with the full battery of covariates (columns 2 and 4$).{ }^{16}$ Thus, this placebo treatment exercise provides supportive evidence for the validity of the key identifying assumption of the difference-in-differences approach, namely that treatment and control group counties follow the same fertility trend in absence of the treatment. It is only after the federal initiatives to expand child care that we observe a positive divergence in coverage rates and, closely following this treatment, a positive divergence in birth rates driven by a fertility increase in the treatment group counties.

In order to make sure that the results are not contingent on the decision to use the median child care expansion as the cut-off for defining treatment and control group,

\footnotetext{
${ }^{15}$ Calculated with a baseline birth rate from 2002 for the treatment group.

${ }^{16}$ Note that the reason why we choose this period of observation for our placebo treatment test is that there are no difference in child care between treatment and control group in these pre-treatment years. Therefore, we cannot rescale the ITT effects of this placebo treatment test to obtain ATT effects.
} 
Table 4: Difference-in-differences estimates

\begin{tabular}{|c|c|c|c|c|c|}
\hline & & \multicolumn{2}{|c|}{$\begin{array}{c}\text { Birth rate } \\
\mathrm{t}\end{array}$} & \multicolumn{2}{|c|}{$\begin{array}{l}\text { Birth rate } \\
\quad t+1\end{array}$} \\
\hline & & (1) & $(2)$ & (3) & (4) \\
\hline $\begin{array}{l}\text { (i) DD - Median } \\
\text { Phase II effect }\end{array}$ & $\begin{array}{l}I T T \\
A T T\end{array}$ & $\begin{array}{c}0.973^{* * *} \\
(0.299) \\
14.898^{* * *}\end{array}$ & $\begin{array}{c}0.827^{* * *} \\
(0.209) \\
12.671^{* * *}\end{array}$ & $\begin{array}{c}1.062^{* * *} \\
(0.281) \\
16.259^{* * *}\end{array}$ & $\begin{array}{c}0.815^{* * *} \\
(0.201) \\
12.483^{* * *}\end{array}$ \\
\hline Phase I effect & $\begin{array}{l}I T T \\
A T T\end{array}$ & $\begin{array}{l}0.467^{*} \\
(0.238) \\
10.410^{*}\end{array}$ & $\begin{array}{c}0.410^{* *} \\
(0.174) \\
9.130^{* *}\end{array}$ & $\begin{array}{c}0.611^{* * *} \\
(0.226) \\
13.610^{* * *}\end{array}$ & $\begin{array}{c}0.444^{* * *} \\
(0.160) \\
9.885^{* * *}\end{array}$ \\
\hline $\begin{array}{l}R^{2} \\
\mathrm{~N}\end{array}$ & & $\begin{array}{l}0.668 \\
3,900\end{array}$ & $\begin{array}{l}0.883 \\
3,900\end{array}$ & $\begin{array}{l}0.638 \\
3,900\end{array}$ & $\begin{array}{l}0.867 \\
3,900\end{array}$ \\
\hline $\begin{array}{l}\text { (ii) DD - P40/P60 } \\
\text { Phase II effect }\end{array}$ & $\begin{array}{l}\text { ITT } \\
\text { ATT }\end{array}$ & $\begin{array}{c}1.210^{* * *} \\
(0.331) \\
15.322^{* * *}\end{array}$ & $\begin{array}{c}0.967^{* * *} \\
(0.247) \\
12.247^{* * *}\end{array}$ & $\begin{array}{c}1.286^{* * *} \\
(0.306) \\
16.287^{* * *}\end{array}$ & $\begin{array}{c}0.892^{* * *} \\
(0.229) \\
11.296^{* * *}\end{array}$ \\
\hline Phase I effect & $\begin{array}{l}I T T \\
A T T\end{array}$ & $\begin{array}{c}0.551^{* *} \\
(0.264) \\
10.09^{* *}\end{array}$ & $\begin{array}{c}0.466^{* *} \\
(0.201) \\
8.548^{* *}\end{array}$ & $\begin{array}{c}0.772^{* * *} \\
(0.251) \\
14.14^{* * *}\end{array}$ & $\begin{array}{c}0.512^{* * *} \\
(0.189) \\
9.377^{* * *}\end{array}$ \\
\hline $\begin{array}{l}R^{2} \\
\mathrm{~N}\end{array}$ & & $\begin{array}{l}0.685 \\
3,120\end{array}$ & $\begin{array}{l}0.886 \\
3,120\end{array}$ & $\begin{array}{l}0.661 \\
3,120\end{array}$ & $\begin{array}{l}0.871 \\
3,120\end{array}$ \\
\hline $\begin{array}{l}\text { (iii) Placebo DD } \\
\text { Placebo effect }\end{array}$ & & $\begin{array}{l}-0.021 \\
(0.212)\end{array}$ & $\begin{array}{c}0.023 \\
(0.169)\end{array}$ & $\begin{array}{c}0.091 \\
(0.210)\end{array}$ & $\begin{array}{l}-0.026 \\
(0.165)\end{array}$ \\
\hline $\begin{array}{l}R^{2} \\
\mathrm{~N}\end{array}$ & & $\begin{array}{l}0.816 \\
2,275\end{array}$ & $\begin{array}{l}0.909 \\
2,275\end{array}$ & $\begin{array}{l}0.781 \\
2,275\end{array}$ & $\begin{array}{l}0.901 \\
2,275\end{array}$ \\
\hline $\begin{array}{l}\text { Regional controls } \\
\text { County FE }\end{array}$ & & $\begin{array}{l}\text { No } \\
\text { Yes }\end{array}$ & $\begin{array}{l}\text { Yes } \\
\text { Yes }\end{array}$ & $\begin{array}{l}\text { No } \\
\text { Yes }\end{array}$ & $\begin{array}{l}\text { Yes } \\
\text { Yes }\end{array}$ \\
\hline
\end{tabular}

Notes: The table shows results of difference-in-differences estimations. In the top panel, the treatment group consists of all counties with above median increase in child care coverage rates from 2002 until 2009. The control group consists of counties with below median increase in child care coverage rates from 2002 until 2009. In the middle panel, counties between the 40th and 60 percentile of the child care growth distribution are left out from the treatment and control group. In the upper two panels, the Phase II effect is the treatment effect for 2008 and 2009 and the Phase I effect is the treatment effect for 2005 through 2007, with a baseline period of 1998 through 2004. ATT is the ITT rescaled by the average treatment intensity for 2008 and 2009 resp. 2005 through 2007, defined as the average increase in child care coverage rates compared to 2002. In the bottom panel, the baseline period is 1998 through 2001 and the placebo period is 2002 through 2004, the treatment group is defined as in the top panel. County FE denotes the inclusion of county fixed effects in the regressions. Regional control variables include the county's population density, GDP per capita, the male employment rate, the interpolated conservative vote share as well as an extensive set of age structure controls. Age structure control variables include the year-of-age share of 15 to 44 year old women over all women aged 15 to 44 and the year-of-age shares of 45 to 74 year old and 75 plus years old people over the population in each county. Robust standard errors are clustered at the county level and given in parentheses. ${ }^{* * *} 1$ percent significance level; ${ }^{* *} 5$ percent significance level; * 10 percent significance level. 
we now drop observations from the 40th to 60th percentile of the child care increase distribution. Running the difference-in-differences regressions on the restricted subsample, we find very similar results as can be seen from panel (ii) in Table 4. The ITT estimates again turn out to be positive, significant and increasing from the Phase I to the Phase II period. Note that the treatment, i.e., the difference in child care expansion between treatment and control group counties, is slightly stronger in this subsample since we drop counties with medium child care expansion from the treatment and control group. Rescaling the resulting difference-in-differences estimators by the difference in treatment intensity yields ATT effects that are remarkably similar to the effects identified for the whole sample.

\subsection{Fixed-effects results}

We now turn to a more generalized county fixed-effects model which restricts the marginal effects of increases in child care to be constant and avoids any problems with the exact definition of treatment and control group. Apart from county fixed effects, we control for year fixed effects to account for year specific changes in fertility. Furthermore, in all regressions we include a county's population density to capture changes in regional agglomeration, the male employment rate to control for local labor market developments, GDP per capita to account for changes in local prosperity, and the conservative vote share to capture regional changes in political attitudes. Moreover, we capture emerging differences in the population age structure by including as additional covariates the age specific shares in the subsample of women aged 15 to 44 as well as the age specific shares of 45 year olds and older in the total population. In contrast to the DD results, for estimating marginal effects of child care we have to constrain the sample to those years when information on child care is available. Again, we report estimates for the effect of child care on birth rates in year $t$ as well as in year $t+1$. The results of these county fixed effects regressions are reported in Table 5.

As can be seen from column 1, the fixed effects model suggests that increasing child care by 10 percentage points leads to an increase in birth rates by 1.183 in year $t$. Using the average birth rates in our sample this corresponds to a $2.7 \%$ increase. The effect of a 10 percentage point increase in child care in year $t$ on the birth rate in year $t+1$ is estimated to be 1.235 or $2.8 \%$ (column 2 of Table 5 ). Thus, the fixed effects model yields very similar effects to the difference-in-differences model. Again the results turn out to be statistically highly significant and economically substantial.

Unobserved time-varying factors that correlate with both child care expansion and fertility are potential threats to identification. Apart from the regional characteristics already included as covariates, one might want to control for local public finance. Local public finance might be a determinant of child care expansion; at the same time, prosperous municipalities might be able to provide an attractive environment for young couples to have children. In order to rule out that the results are driven by these potential confounding factors, we include municipalities' gross revenue and debts as well as the number of new dwellings in a county as additional control variables in the county fixed effects model. ${ }^{17}$ Columns 3 and 4 of Table 5 show that the effect of child care on the birth

\footnotetext{
${ }^{17}$ Unfortunately, the debt and revenue variables are not available for the city states of Hamburg and Bremen. Moreover, information on municipalities' gross revenue is missing for all counties in the state of
} 
Table 5: County fixed effects estimates

\begin{tabular}{|c|c|c|c|c|}
\hline & \multicolumn{4}{|c|}{ Birth rate } \\
\hline & $\begin{array}{c}\mathrm{t} \\
(1)\end{array}$ & $\begin{array}{l}t+1 \\
(2)\end{array}$ & $\begin{array}{c}\mathrm{t} \\
(3)\end{array}$ & $\begin{array}{c}t+1 \\
(4)\end{array}$ \\
\hline Child care coverage & $\begin{array}{c}11.833^{* * *} \\
(2.594)\end{array}$ & $\begin{array}{c}12.345^{* * *} \\
(2.429)\end{array}$ & $\begin{array}{c}12.644^{* * *} \\
(3.027)\end{array}$ & $\begin{array}{c}13.099 * * * \\
(2.839)\end{array}$ \\
\hline Revenue, debt, dwellings & No & No & Yes & Yes \\
\hline Regional controls & Yes & Yes & Yes & Yes \\
\hline Year FE & Yes & Yes & Yes & Yes \\
\hline County FE & Yes & Yes & Yes & Yes \\
\hline $\mathrm{N}$ & 1,950 & 1,950 & 1,610 & 1,610 \\
\hline Number of counties & 325 & 325 & 322 & 322 \\
\hline F-statistic & 74.69 & 56.50 & 70.38 & 54.25 \\
\hline \multicolumn{5}{|c|}{$\begin{array}{l}\text { Notes: The table shows the results of county fixed-effects estimations. The outcome } \\
\text { variable births per } 1,000 \text { women aged } 15 \text { to } 44 \text { is measured in period t columns (1) and } \\
\text { (3), and forwarded by one period in columns }(2) \text { and (4). Regional control variables } \\
\text { include the county's population density, GDP per capita, the male employment rate, } \\
\text { the interpolated conservative vote share as well as an extensive set of age structure } \\
\text { controls. Age structure control variables include the year-of-age share of } 15 \text { to } 44 \\
\text { year old women over all women aged } 15 \text { to } 44 \text { and the year-of-age shares of } 45 \text { to } \\
74 \text { year old and } 75 \text { plus years old people over the population in each county. Debt } \\
\text { and revenue of municipalities are not reported for the federal city states Hamburg and } \\
\text { Bremen (including Bremerhaven). Revenue information is missing in } 2001 \text { from all } \\
15 \text { Schleswig-Holstein counties. Revenue information in } 2009 \text { is not included due to } \\
\text { fragmentary raw data. Dwellings denotes controls for the number of newly built homes. } \\
\text { Robust standard errors are clustered at the county level and given in parentheses. *** } 1 \\
\text { percent significance level; ** } 5 \text { percent significance level; * } 10 \text { percent significance level. }\end{array}$} \\
\hline
\end{tabular}

rate stays highly significant and positive. Indeed, the point estimates of 12.644 in $t$ and 13.099 in $t+1$ are if anything larger than the estimates from columns 1 and 2 .

5.3.1. Effect heterogeneity and children's birth outcomes The birth registry data includes valuable background information on individual births. In particular, we know the age and the marital status of all women giving birth. We exploit this information in order to investigate the heterogeneity of the effects of child care on fertility. First, we merge the birth registry data with the administrative regional population data to compute agespecific birth rates. We then run separate county fixed effects models for all age-specific birth rates. Figure 5 depicts the point estimates and 90 percent confidence intervals for the effects of child care on age-specific birth rates. We find positive effects of child care almost throughout the entire age distribution. The effects turn out to be particularly strong and significant for women aged 30 to 34 . A 10 percentage point increase in child care increases the number of births in this age group by $3.3 \%$, resulting in more than 6,000 additional births to women aged 30 to 34 (see Table A.5 in the Appendix).

Second, we investigate whether fertility responds to increases in child care at the extensive or at the intensive margin. Within given marriages, the birth registry data provides additional information on the birth order of children. We split the number of births by marital status and find that the fertility effects of child care seem to be driven by married women, which suggests that this restriction to within-marriage births is no major drawback. Also, the vast majority of births occurs within marriages. We then

Schleswig-Holstein in 2001; since gross revenue information is very fragmentary in 2009, we have to drop this year from our sample. 
Figure 5: Child care effect on year-of-age specific birth rates

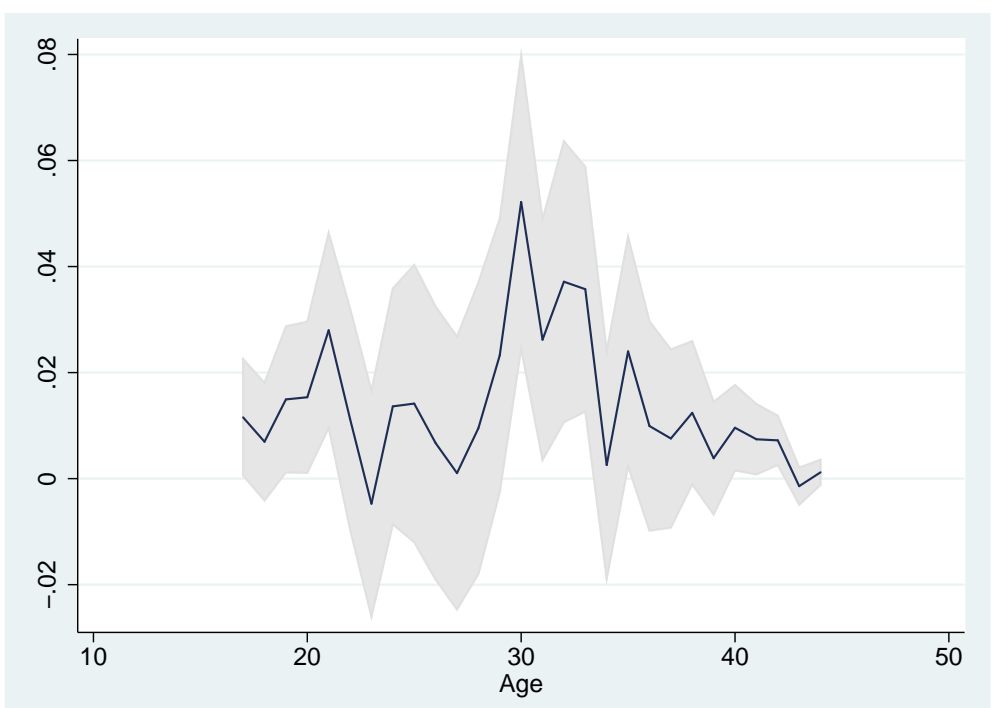

Notes: The figure shows the effect of child care coverage on year-of-age specific birth rates in period t+1 from county fixedeffects regressions. The middle line denotes the average marginal effect, the grey area depicts $90 \%$ confidence intervals. All regressions are performed including the control variables as in the baseline estimation. County and year fixed effects are included. Regional control variables include the county's population density, GDP per capita, the male employment rate, the interpolated conservative vote share as well as an extensive set of age structure controls. Age structure control variables include the year-of-age share of 15 to 44 year old women over all women aged 15 to 44 and the year-of-age shares of 45 to 74 year old and 75 plus years old people over the population in each county.

construct variables measuring the number of first births, second births, third births, and fourth births per 1,000 women of reproductive age in a county. County fixed effects models for these birth order specific birth rates show that child care particularly increases the number of second and third births. The highly significant point estimates suggest that a 10 percentage point increase in child care increases the incidence of second and third births by $3.9 \%$ and $7.5 \%$, respectively. The effect on first births is $0.5 \%$ in $t$ and $2.2 \%$ $t+1$, where only the latter is statistically significant. Thus, the pattern suggests that the effects of child care on fertility are stronger at the intensive than at the extensive margin (see Table 6).

Third, we are interested in the question whether increases in child care affect the health outcomes of babies at birth. This might be the case if the expansion of child care changes the composition of parents (Dehejia and Lleras-Muney, 2004). Marginal babies, who would not have been born without the reform, might have poorer starting conditions. The birth registry data provides information on each child's birth height (in $\mathrm{cm}$ ) and birth weight (in gram). In addition to these two measures, we compute a low birth weight indicator variable which equals unity for birth weights below 2,500 grams. Moreover, we combine the birth weight and birth height information in a Ponderal index, defined as weight (in $\mathrm{kg}$ ) by height (in meter ${ }^{3}$ ). Using the county average of these four birth outcome measures as dependent variables in the fixed effects models, we find no clear effects of child care on babies' health outcomes. Regression results in Table 7 show insignificant estimates for the effect of child care on birth height and birth weight in period $t+1$. The point estimate for birth height is $0.18 \mathrm{~cm}$, which corresponds to less than a half percent of the average birth height of $51 \mathrm{~cm}$. Not only is the estimate very small, it is a rather precisely estimated zero effect. The point estimate for birth weight of -44.15 
Table 6: Birth order specific birth rates

\begin{tabular}{|c|c|c|c|c|c|c|c|c|}
\hline & \multicolumn{8}{|c|}{ Birth order specific birth rate } \\
\hline & \multicolumn{2}{|c|}{ 1st births } & \multicolumn{2}{|c|}{ 2nd births } & \multicolumn{2}{|c|}{ 3rd births } & \multicolumn{2}{|c|}{ 4th births } \\
\hline & $\begin{array}{c}\mathrm{t} \\
(1) \\
\end{array}$ & $\begin{array}{c}\mathrm{t}+1 \\
(2)\end{array}$ & $\begin{array}{c}\mathrm{t} \\
(3) \\
\end{array}$ & $\begin{array}{c}t+1 \\
(4)\end{array}$ & $\begin{array}{c}\mathrm{t} \\
(5) \\
\end{array}$ & $\begin{array}{c}t+1 \\
(6)\end{array}$ & $\begin{array}{c}\mathrm{t} \\
(7) \\
\end{array}$ & $\begin{array}{c}\mathrm{t}+1 \\
(8)\end{array}$ \\
\hline Child care coverage & $\begin{array}{c}0.770 \\
(1.499)\end{array}$ & $\begin{array}{l}3.287^{* *} \\
(1.402)\end{array}$ & $\begin{array}{c}5.015^{* * *} \\
(1.174)\end{array}$ & $\begin{array}{c}5.298^{* * *} \\
(1.226)\end{array}$ & $\begin{array}{c}3.214^{* * *} \\
(0.687)\end{array}$ & $\begin{array}{c}3.007^{* * *} \\
(0.653)\end{array}$ & $\begin{array}{l}0.545^{*} \\
(0.302)\end{array}$ & $\begin{array}{c}0.435 \\
(0.303)\end{array}$ \\
\hline Regional controls & Yes & Yes & Yes & Yes & Yes & Yes & Yes & Yes \\
\hline Year FE & Yes & Yes & Yes & Yes & Yes & Yes & Yes & Yes \\
\hline County FE & Yes & Yes & Yes & Yes & Yes & Yes & Yes & Yes \\
\hline $\begin{array}{l}\text { Percent effect of 10pp } \\
\text { childcare increase }\end{array}$ & 0.005 & 0.022 & 0.039 & 0.041 & 0.075 & 0.070 & 0.048 & 0.038 \\
\hline $\mathrm{N}$ & 1,950 & 1,950 & 1,950 & 1,950 & 1,950 & 1,950 & 1950 & 1,950 \\
\hline Number of counties & 325 & 325 & 325 & 325 & 325 & 325 & 325 & 325 \\
\hline F-statistic & 119.5 & 64.05 & 96.08 & 91.30 & 33.05 & 27.78 & 13.91 & 9.137 \\
\hline
\end{tabular}

grams, which corresponds to 1.3 percent of average birth weights, is small and statistically insignificant. If we cannot rule out a reduction in birth weight completely, this would be a concern if the reduction was driven by changes at the lower end of the birth weight distribution. Looking at the effect of child care on the low birth weight indicator suggests that birth weights do not change for the worse. The point estimate for low birth weight is small, negative and statistically insignificant. Thus, the evidence is if anything indicative of a reversion to the mean in birth weights. Finally, the estimate on the Ponderal index turns out to be significant, but the point estimate is small. Again, it is not entirely clear whether a lower index is to be interpreted as a sign of inferior health as the reduction might also be driven by greater height or less overweight. Considering that mothers' age and birth parity increase as a result of the reform, it is remarkable that the marginal child hypothesis does not seem to hold in terms of inferior health at birth.

Fourth, in unreported regressions we investigate effect heterogeneity at the regional level. Of course, one should be cautious with the interpretation of these analyses since one cannot infer from effect heterogeneity with respect to regional characteristics that the heterogeneity is actually driven by individuals that carry the respective characteristics (ecological fallacy). Nevertheless, comparing estimates across different samples of counties might still yield interesting patterns about mediating factors. The results from fixed effects models show that the effect of child care on fertility tends to be larger in counties with a higher GDP, lower conservative vote share and a larger share of higher secondary school graduates, which serves as a proxy for a county's share of high-skilled individuals. ${ }^{18}$

In sum, the county fixed effects models yield consistent evidence that child care positively affects fertility. An increase in the coverage rate by 10 percentage points increases birth rates by about $2.7 \%$ in $t$ and $2.8 \%$ in $t+1$. The effect is driven to a large extent

${ }^{18}$ Detailed results are available from the authors upon request. 
Table 7: Investigating marginal birth outcomes

\begin{tabular}{|c|c|c|c|c|}
\hline & $\begin{array}{c}\text { Birth } \\
\text { height }(\mathrm{cm}) \\
\mathrm{t}+1 \\
(1)\end{array}$ & $\begin{array}{c}\text { Birth } \\
\text { weight (grams) } \\
\mathrm{t}+1 \\
(2)\end{array}$ & $\begin{array}{c}\text { Low birth } \\
\text { weight } \\
\text { t+1 } \\
(3)\end{array}$ & $\begin{array}{l}\text { Ponderal } \\
\text { index } \\
\mathrm{t}+1 \\
(4)\end{array}$ \\
\hline Child care coverage & $\begin{array}{c}0.182 \\
(0.284)\end{array}$ & $\begin{array}{l}-44.157 \\
(32.566)\end{array}$ & $\begin{array}{c}-0.012 \\
(0.013)\end{array}$ & $\begin{array}{c}-0.744^{* *} \\
(0.368)\end{array}$ \\
\hline Regional controls & Yes & Yes & Yes & Yes \\
\hline Year FE & Yes & Yes & Yes & Yes \\
\hline County FE & Yes & Yes & Yes & Yes \\
\hline $\mathrm{N}$ & 1,945 & 1,945 & 1,945 & 1,945 \\
\hline Number of counties & 325 & 325 & 325 & 325 \\
\hline F-statistic & 5.14 & 14.00 & 2.60 & 5.35 \\
\hline \multicolumn{5}{|c|}{ 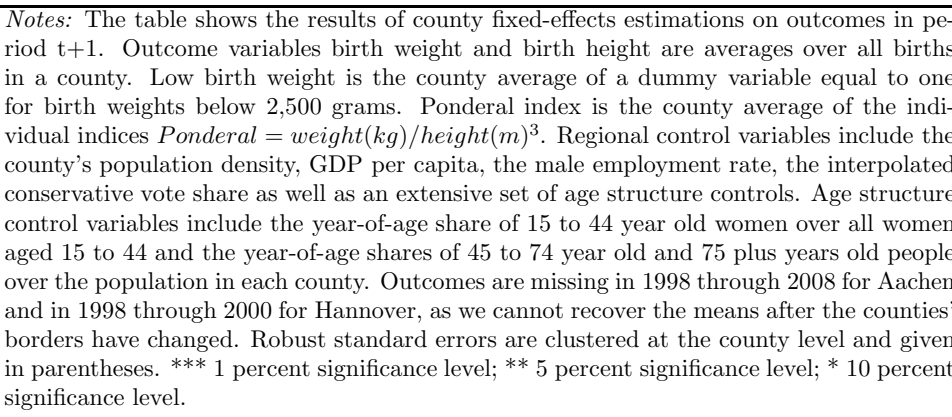 } \\
\hline
\end{tabular}

by higher order births to married women aged between 30 and 34 and tends to be higher in counties with rather liberal attitudes and a larger share of highly educated individuals. Children born in response to an increase in child care do not show inferior health outcomes, such as a higher prevalence of low birth weight or a lower birth height.

5.3.2. Selective migration Although we control for unobserved time-invariant heterogeneity between counties and include an extensive set of time-varying county characteristics, selective migration of potential mothers might confound the estimates. In particular, if couples or women who are pregnant or plan to have a child systematically move to counties that substantially increase child care, the regressions would yield upward biased estimates of the effect of child care on fertility. However, also note that movements to counties that have always been known for a family-friendly infrastructure do not confound the estimates: as long as this kind of selective migration is constant over time, it is captured by the county fixed effects. ${ }^{19}$

If increases in child care redirect migration flows of mothers-to-be, this should show up in the data in the form of higher gross in-migration flows or lower gross out-migration flows in counties that substantially increase coverage rates. In order to test whether this is the case, we run the fixed-effects regressions using the ratio of female in-migrants aged 18 to 29 in $t+1$ over the total population in $t$ as the outcome variable (row 1 of Table 8). As an alternative outcome variable, we use the ratio of female in-migrants aged 18 to 49

\footnotetext{
${ }^{19}$ Similarly, the results are not confounded by the movement of couples or single mothers with a baby since the outcome variable does not measure the number of under three year olds but the actual number of births in a county.
} 
Table 8: Fixed-effects estimates on gross migration flows and commuting

\begin{tabular}{|c|c|c|c|c|c|c|}
\hline & $\begin{array}{c}\text { Child care } \\
\text { coverage } \\
(1)\end{array}$ & $\begin{array}{c}\text { Regional } \\
\text { controls } \\
(2)\end{array}$ & $\begin{array}{c}\text { Year \& } \\
\text { county FE } \\
(3)\end{array}$ & $\begin{array}{l}\mathrm{N} \\
\text { (4) }\end{array}$ & $\begin{array}{c}\text { Counties } \\
\text { (5) }\end{array}$ & $\begin{array}{c}\text { F-stat } \\
(6)\end{array}$ \\
\hline \multicolumn{7}{|l|}{ Dependent var } \\
\hline $\begin{array}{l}\text { In-migrants } 18-29 \text { per pop, } \\
\text { female }(t+1)\end{array}$ & $\begin{array}{c}0.002 \\
(0.001)\end{array}$ & Yes & Yes & 1,625 & 325 & 4.7 \\
\hline $\begin{array}{l}\text { In-migrants } 18-49 \text { per pop, } \\
\text { female }(t+1)\end{array}$ & $\begin{array}{c}0.001 \\
(0.002)\end{array}$ & Yes & Yes & 1,625 & 325 & 5.5 \\
\hline $\begin{array}{l}\text { Out-migrants } 18-29 \text { per pop, } \\
\text { female }(\mathrm{t}+1)\end{array}$ & $\begin{array}{l}-0.001 \\
(0.001)\end{array}$ & Yes & Yes & 1,625 & 325 & 21.4 \\
\hline $\begin{array}{l}\text { Out-migrants } 18-49 \text { per pop, } \\
\text { female }(t+1)\end{array}$ & $\begin{array}{l}-0.004 \\
(0.002)\end{array}$ & Yes & Yes & 1,625 & 325 & 11.3 \\
\hline $\begin{array}{l}\text { Commuter (out) per pop, } \\
\text { female }(t+1)\end{array}$ & $\begin{array}{c}0.013^{* * *} \\
(0.004)\end{array}$ & Yes & Yes & 1,747 & 325 & 102.8 \\
\hline $\begin{array}{l}\text { Commuter (out) per pop, } \\
\text { male }(t+1)\end{array}$ & $\begin{array}{l}-0.005 \\
(0.006)\end{array}$ & Yes & Yes & 1,747 & 325 & 45.6 \\
\hline \multicolumn{7}{|c|}{$\begin{array}{l}\text { Notes: The table shows the results of county fixed-effects estimations. The outcome variables are denoted in } \\
\text { rows. Regional control variables include the county's population density, GDP per capita, the male employment } \\
\text { rate, the interpolated conservative vote share as well as an extensive set of age structure controls. Age structure } \\
\text { control variables include the year-of-age share of } 15 \text { to } 44 \text { year old women over all women aged } 15 \text { to } 44 \text { and the } \\
\text { year-of-age shares of } 45 \text { to } 74 \text { year old and } 75 \text { plus years old people over the population in each county. Estimates } \\
\text { in rows are from independent regressions. Robust standard errors are clustered at the county level and given } \\
\text { in parentheses. }{ }^{* * *} 1 \text { percent significance level; } * * * 5 \text { percent significance level; } * 10 \text { percent significance level. }\end{array}$} \\
\hline
\end{tabular}

in $t+1$ over the total population in $t$ as the outcome variable (row 2 of Table 8 ). We do not find any evidence that child care affects gross in-migration of women of reproductive age. Similarly, we do not find any effects of child care on female gross out-migration as can be seen in rows 3 and 4 of Table 8 . Using gross in-migration and out-migration of women of reproductive age in $t$ instead of $t+1$ as alternative outcome variables leaves the results unchanged. Thus, these fixed-effects regressions corroborate the previous results and speak against selective migration biasing our findings.

We further investigate the issue of selective migration by using administrative data on commuting incidences. If the motivation for choosing the place of residence was driven by increasing child care rather than job opportunities, we would expect more people to commute out of the county with high child care expansion. This is because the place of residence determines the eligibility for child care slots but not the workplace. We run fixed effects regressions using the share of female and male commuters over the total population as the outcome variable. The results depicted in rows 5 and 6 of Table 8 show that child care indeed increases the share of female commuters, yet not the share of male commuters. If there was selective choice of families' residence with respect to child care expansion, we would expect an equal effect on commuting patterns between the sexes as it affects the couple as a whole. This is not the case; rather, the commuting pattern is compatible with a story where child care increases maternal employment, which results in a higher number of female commuters.

5.3.3. Timing of the fertility response We exploit the variation of child care over time to identify effects on an outcome (births) that can only react with a certain lag. Therefore, it is essential for our analysis to get the timing of cause and effect right. We have decided to estimate the effect of child care in period $t$ both on births in period $t$ and on births in 
period $t+1$. Remember that child care is measured at the beginning of March and births are measured as the sum of births in a specific year. As child care centers typically align their service to school years (August or September to June or July), the coverage rate measured in March may partly reflect coverage from August or September in the year before. Furthermore, utilized child care slots in March must have been established some time in the preceding 12 months. As a consequence, fertility may already react to changes in child care in period $t$. Using births in period $t+1$ as an additional outcome variable means that we allow some more time for conception and pregnancy - in sum 10 to 22 months after child care is observed in March. Although the scope of our conception and gestation lag is in line with the literature on fertility responses to public policies (see, e.g., Rindfuss et al. (2010)), we would like to also test empirically whether this specification is valid.

In Figure 6, we show effects of child care measured in period $t$ on births in period $x$, while controlling for child care and all other covariates in period $x-1$. Accordingly, in the fourth column $(x=t+1)$ we observe the effect of child care in $t$ on births in $t+1$, which is exactly the baseline effect from the fixed-effects estimation on births in $t+1$ (12.345). To check whether our timing specification is reasonable, we now shift the outcome and control variables on the timeline. The middle bar reveals that even if we control for the relevant child care in $t-1$, child care in $t$ has a positive and significant effect on births in $t$.

The expansion of child care within counties might not be independent over periods. In that case, the fixed-effects regressions could be spurious. To be sure that we do not only pick up pure child care expansion trajectories, we estimate the effect of child care in $t$ on births in $t+2$ while controlling for child care in $t+1$. As can be seen from the far right bar, there is no significant effect of child care in $t$ on births in $t+2$. We apply the same procedure for the other direction on the timeline and find that there is no effect of child care in $t$ on births in $t-1$ (and $t-2$ respectively), conditional on child care in $t-2$ (and $t-3$ - respectively). Indeed, the coefficients are very close to zero and far away from any conventional significance levels, which also provides evidence against any reverse causality concerns. Taken together, our decision to investigate the effects of child care in $t$ on births in $t$ and $t+1$ is not only in line with the previous literature but also empirically well founded.

5.3.4. Tempo effects Our measure of birth rates, births per 1,000 women aged 15 to 44, is a period fertility measure and therefore disregards year-of-age specific birth rates. The measure shares most features with the total fertility rate and is as such suitable to analyze the effects of policy changes. Yet, in contrast to cohort fertility, which reflects the actual number of births per woman measured after the reproductive age, it can be distorted by changes in the timing of births (tempo effects). If couples, as a response to the child care expansion, decide to have children earlier in life but not to have more children over the course of life, we might see a short-term increase in period fertility although there is no long-term effect on completed fertility.

Therefore, we now investigate in more detail whether the fertility effects we uncovered can be interpreted as pieces of evidence for a positive long-term fertility effect or are rather due to tempo effects. If the results are just due to tempo effects, we should observe 
Figure 6: Timing of the dependent variable

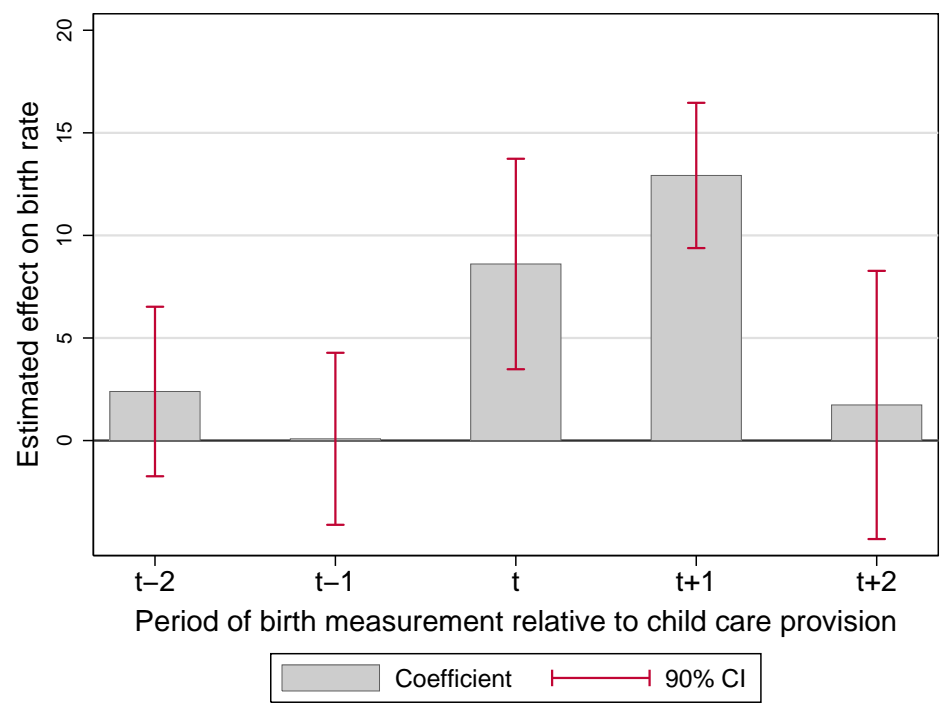

Notes: The bars indicate the effect of child care coverage in period t on births per 1,000 women in the period according to the x-axis. Red lines indicate 90-percent confidence intervals. All five regressions are independently estimated using the fixed-effects approach. Control variables including child care coverage are lagged by one year and are included in period $\mathrm{x}-1$. Only for $\mathrm{x}-1=\mathrm{t}$ the control variable child care coverage is identical to the variable of interest child care coverage in period $t$.

larger effects of child care on fertility for younger cohorts than for older cohorts of women. This does not seem to be the case. Figure 5 shows positive effects throughout the age distribution with the strongest effects for women aged 30 to 34 .

Still, to look more deeply into this problem, we use the fixed effects specification to estimate the effect of child care on mothers' age at birth separately for first births, second births, third births, and fourth births. As can be seen from Table 9, we find no evidence at all that women get children earlier in life in response to increases in child care. The evidence rather points in the opposite direction: the average age of women both at the second birth rather increases than decreases in response to child care expansion. ${ }^{20}$ Thus, instead of inducing individuals to prepone fertility, child care expansion seems to have inspired women aged 30 and older to have more children. As a consequence, the effect of child care on births identified in this paper does not seem due to short-term tempo effects. Rather, we expect child care to have positive effects on long-term completed fertility.

\section{Concluding Remarks}

The question of whether family policies, such as affordable child care, can positively affect the private choice to have children has gained importance over the past decades. Although the literature on this subject has grown recently, most of what we know about the effects of child care policy on fertility comes from countries where fertility rates are close to replacement levels. An important remaining challenge for empirical research is to understand if child care policy can positively influence childbearing decisions in countries

\footnotetext{
${ }^{20}$ Estimates for fourth births should be interpreted with caution as they are based on few observations. Less than $4 \%$ of all births within marriages are fourth births.
} 
Table 9: Age at birth by birth order

\begin{tabular}{lcccccccc}
\hline & \multicolumn{1}{c}{ Mothers' age at birth } & \multicolumn{2}{c}{} \\
& 1st births & \multicolumn{2}{c}{ 2nd births } & \multicolumn{2}{c}{ 3rd births } & \multicolumn{2}{c}{ th births } \\
& $\mathrm{t}$ & $\mathrm{t}+1$ & $\mathrm{t}$ & $\mathrm{t}+1$ & $\mathrm{t}$ & $\mathrm{t}+1$ & $\mathrm{t}$ & $\mathrm{t}+1$ \\
& $(1)$ & $(2)$ & $(3)$ & $(4)$ & $(5)$ & $(6)$ & $(7)$ & $(8)$ \\
\hline Child care coverage & -0.047 & 0.001 & $0.783^{*}$ & 0.156 & 0.302 & -0.178 & 1.618 & $2.292^{*}$ \\
& $(0.422)$ & $(0.389)$ & $(0.414)$ & $(0.430)$ & $(0.629)$ & $(0.730)$ & $(1.150)$ & $(1.165)$ \\
Regional controls & Yes & Yes & Yes & Yes & Yes & Yes & Yes & Yes \\
Year FE & Yes & Yes & Yes & Yes & Yes & Yes & Yes & Yes \\
County FE & Yes & Yes & Yes & Yes & Yes & Yes & Yes & Yes \\
\hline N & 1,950 & 1,950 & 1,950 & 1,950 & 1,950 & 1,950 & 1950 & 1,950 \\
Number of counties & 325 & 325 & 325 & 325 & 325 & 325 & 325 & 325 \\
F-statistic & 112.6 & 85.61 & 120.0 & 105.2 & 41.03 & 31.66 & 15.92 & 11.21 \\
\hline Notes: The tabs
\end{tabular}

Notes: The table shows the results of county fixed-effects estimations. The outcome variables are mothers'
average age at birth by within-marriage birth order, i.e., the average age of mothers at 1st births (column 1), 2nd births (column 2), 3rd births (column 3), and 4th births (column 4). All outcome variable are forwarded by one period. Regional control variables include the county's population density, GDP per capita, the male employment rate, the interpolated conservative vote share as well as an extensive set of age structure controls. Age structure control variables include the year-of-age share of 15 to 44 year old women over all women aged 15 to 44 and the year-of-age shares of 45 to 74 year old and 75 plus years old people over the population in each county. Robust standard errors are clustered at the county level and given in parentheses. *** 1 percent significance level; $* * 5$ percent significance level; $* 10$ percent significance level.

where birth rates are considered to be "too low". In this paper, we have made a first step towards such an understanding by evaluating the impact on fertility of a major German child care reform. The reform we study led to a significant expansion of child care slots for young children, and our empirical strategy exploits the temporal and spatial variation in child care coverage induced by this expansion. First, we apply a difference-indifferences method that compares a treatment group of counties with above-median child care expansion to a control group of counties with below-median child care expansion over time. Second, we use a fixed-effects estimator that utilizes the full variation in treatment intensities. Results from both specifications show consistently that child care expansion has a significant positive effect on fertility. In particular, our results suggest a 10 percentage point increase in child care coverage leads to an increase in birth rates of $2.8 \%$. Results are neither confounded by regional fundamentals and demographics nor by selective migration into counties with strong child care expansion. We find no evidence for tempo effects in fertility as a response to the reform and, thus, increases in birth rates are expected to be sustainable. We show that the additional children are mostly of higher order within existing families. Thus, the effects of child care on birth rates materialize mainly at the intensive margin. Despite the higher age of mothers, we find no indication that the marginally born children are of inferior health. Taken together, the results presented in this paper suggest that there is nothing inevitable about very low fertility rates: policies that facilitate the combination of parenthood and employment hold the promise of being an effective way to boost birth rates where these rates are considered to be too low. 


\section{References}

Baker, M., Gruber, J. and Milligan, K. (2008). Universal Childcare, Maternal Labor Supply, and Family Well-Being. Journal of Political Economy, 116 (4), 709-745.

Becker, G. S. (1960). An Economic Analysis of Fertility. In Demographic and Economic Change in Developed Countries, Universities-National Bureau Conference Series No. 11, Princeton: Princeton University Press.

- and Lewis, G. H. (1973). On the Interaction between the Quantity and Quality of Children. Journal of Political Economy, 81 (2), S279-S288.

BIck, A. (2013). The Quantitative Role of Child Care for Female Labor Force Participation and Fertility. Arizona State University mimeo.

Bien, W., Rauschenbach, T. and Riedel, B. (2006). Wer betreut Deutschlands Kinder? DJI-Kinderbetreuungsstudie, München.

Blau, D. M. and Tekin, E. (2007). The Determinants and Consequences of Child Care Subsidies for Single Mothers. Journal of Population Economics, 20 (4), 719-741.

Cameron, A. C., Gelbach, J. B. and Miller, D. L. (2008). Bootstrap-Based Improvements for Inference with Clustered Errors. The Review of Economics and Statistics, 90 (3), 414-427.

Cascio, E. U. (2009). Maternal Labor Supply and the Introduction of Kindergartens into American Public Schools. Journal of Human Resources, 44 (1), 140-170.

Cigno, A. (1993). Intergenerational Transfers without Altruism: Family, Market and State. European Journal of Political Economy, 9 (4), 505-518.

Dehejia, R. and Lleras-Muney, A. (2004). Booms, Busts, and Babies' Health. Quarterly Journal of Economics, 119 (3), 1091-1130.

Del BocA, D. (2002). The Effect of Child Care and Part Time Opportunities on Participation and Fertility Decisions in Italy. Journal of Population Economics, 15 (3), $549-573$.

-, Pasqua, S. and Pronzato, C. (2009). Motherhood and Market Work Decisions in Institutional Context: a European Perspective. Oxford Economic Papers, 61 (1), i147-i171.

Demeny, P. (1986). Population and the Invisible Hand. Demography, 23 (4), 473-487.

DJI (2005). Zahlenspiegel 2005 - Kinderbetreuung im Spiegel der amtlichen Statistik. Tech. rep.

— (2008). Zahlenspiegel 2007 - Kinderbetreuung im Spiegel der amtlichen Statistik. Tech. rep. 
Dorbritz, J. (2008). Germany: Family Diversity with Low Actual and Desired Fertility. Demographic Research, 19 (17), 557-598.

Ermisch, J. (2003). An Economic Analysis of the Family. Princeton: Princeton University Press.

Felfe, C. and Lalive, R. (2012). Early Child Care and Child Development: For Whom it Works and Why. CESifo Working Paper Series 4043, CESifo Group Munich.

Fenge, R. and Meier, V. (2005). Pensions and Fertility Incentives. Canadian Journal of Economics, 38 (1), 28-48.

Field, T. (1991). Quality Infant Day-Care and Grade School Behavior and Performance. Child Development, 62 (4), 863-870.

Folbre, N. (1994). Children as Public Goods. American Economic Review, 84 (2), 8690 .

Gelbach, J. (2002). Public Schooling for Young Children and Maternal Labor Supply. The American Economic Review, 92 (1), 307-322.

Groezen, B., Leers, T. and Meijdam, L. (2003). Social Security and Endogenous Fertility: Pensions and Child Allowances as Siamese Twins. Journal of Public Economics, 87 (2), 233-251.

Haan, P. and Wrohlich, K. (2011). Can Child Care Policy Encourage Employment and Fertility? Evidence from a Structural Model. Labour Economics, 18 (4), 498-512.

Hank, K. and Kreyenfeld, M. (2003). A Multilevel Analysis of Child Care and Women's Fertility Decisions in Western Germany. Journal of Marriage and Family, 65 (3), 584-596.

- - - and SpIEss, C. K. (2004). Kinderbetreuung und Fertilität in Deutschland. Zeitschrift für Soziologie, 33 (3), 228-244.

-, Tillmann, K. and Wagner, G. G. (2001). Außerhäusliche Kinderbetreuung in Ostdeutschland vor und nach der Wiedervereinigung: ein Vergleich mit Westdeutschland in den Jahren 1990-1999. MPIDR Working Paper 2001-03.

Havnes, T. and Mogstad, M. (2011a). Money for Nothing? Universal Child Care and Maternal Employment. Journal of Public Economics, 95 (11-12), 1455-1465.

— and - (2011b). No Child Left Behind: Universal Child Care and Children's Long-Run Outcomes. American Economic Journal: Economic Policy, 3 (2), 97-129.

Huesken, K. (2011). Kita vor Ort: Betreuungsatlas auf Ebene der Jugendamtsbezirke 2010. Tech. rep.

Jones, L. E., Schoonbroodt, A. and Tertilt, M. (2010). Fertility Theories: Can they explain the Negative Fertility-Income Relationship? In Demography and the Economy, Chicago: University of Chicago Press., pp. 43-100. 
Lefebvre, P. and Merrigan, P. (2002). The Effect of Childcare and Early Education Arrangements on Developmental Outcomes of Young Children. Canadian Public Policy, 28 (2), 159-186.

- and - (2008). Child-Care Policy and the Labor Supply of Mothers with Young Children: A Natural Experiment from Canada. Journal of Labor Economics, 26 (3), 519548.

Leibenstein, H. (1957). Economic Backwardness and Economic Growth. New York: Wiley \& Sons.

Mason, K. and Kuhlthau, K. (1992). The Perceived Impact of Child Care Costs on Womens Labor Supply and Fertility. Demography, 29 (4), 523-543.

Mooney, C. Z. and Duval, R. D. (1993). Bootstrapping: A Nonparametric Approach to Statistical Inference. Newbury Parc, CA: Sage.

Mörk, E., Sjögren, A. and Svaleryd, H. (2013). Childcare Costs and the Demand for Children-Evidence from a Nationwide Reform. Journal of Population Economics, 26, 33-65.

NiCHD - Early Child Care Research Network (2003a). Does Amount of Time Spent in Child Care Predict Socioemotional Adjustment During the Transition to Kindergarten? Child Development, 74 (4), 976-1005.

NICHD - Early Child Care Research Network (2003b). Does Quality of Childcare Affect Child Outcomes at Age 4 $\frac{1}{2}$ ? Developmental Psychology, 39 (3), 451-469.

NiCHD - Early Child Care Research Network (2004). Multiple Pathways to Early Academic Achievement. Harvard Educational Review, 74 (1), 1-29.

Population Reference Bureau (2007). 2007 World Population Data Sheet.

Rindfuss, R. R., Guilkey, D. K., Morgan, S. P. and Kravdal, Ø. (2010). ChildCare Availability and Fertility in Norway. Population and Development Review, 36 (4), $725-748$.

Sinn, H.-W. (2004). The Pay-as-you-go Pension System as Fertility Insurance and an Enforcement Device. Journal of Public Economics, 88 (7), 1335-1357.

Takayama, N. and Werding, M. (2011). Fertility and Public Policy: How to Reverse the Trend of Declining Birth Rates. Cambridge, MA: MIT Press.

Willis, R. J. (1973). A New Approach to the Economic Theory of Fertility Behavior. Journal of Political Economy, 81 (2), S16-S64.

World BAnk (2009). World Development Indicators 2009. Tech. rep.

Wrohlich, K. (2008). The Excess Demand for Subsidized Child Care in Germany. Applied Economics, 40 (10), 1217-1228. 


\section{A. Additional Graphs \& Tables}

Table A.1: Descriptive statistics of age structure controls I

\begin{tabular}{|c|c|c|c|c|c|}
\hline & $\mathrm{N}$ & Mean & S.D. & Min & Max \\
\hline \multicolumn{6}{|c|}{$\begin{array}{l}\text { Female shares per females aged } 15-44 \\
\text { by age }\end{array}$} \\
\hline 15 & 1950 & 0.028 & 0.004 & 0.014 & 0.040 \\
\hline 16 & 1950 & 0.029 & 0.005 & 0.014 & 0.040 \\
\hline 17 & 1950 & 0.029 & 0.005 & 0.015 & 0.041 \\
\hline 18 & 1950 & 0.029 & 0.004 & 0.015 & 0.041 \\
\hline 19 & 1950 & 0.029 & 0.004 & 0.020 & 0.038 \\
\hline 20 & 1950 & 0.029 & 0.003 & 0.020 & 0.050 \\
\hline 21 & 1950 & 0.029 & 0.004 & 0.020 & 0.058 \\
\hline 22 & 1950 & 0.029 & 0.004 & 0.020 & 0.060 \\
\hline 23 & 1950 & 0.028 & 0.005 & 0.020 & 0.060 \\
\hline 24 & 1950 & 0.028 & 0.005 & 0.020 & 0.057 \\
\hline 25 & 1950 & 0.029 & 0.004 & 0.021 & 0.052 \\
\hline 26 & 1950 & 0.029 & 0.004 & 0.022 & 0.048 \\
\hline 27 & 1950 & 0.030 & 0.004 & 22 & .046 \\
\hline 28 & 50 & 0.030 & 0.004 & 22 & 045 \\
\hline 29 & 50 & 0.030 & 0.005 & 23 & 045 \\
\hline 30 & 60 & 0.031 & 0.005 & 0.023 & 046 \\
\hline 31 & 50 & 0.032 & 0.005 & 0.021 & 0.048 \\
\hline 32 & 1950 & 0.032 & 0.005 & 0.020 & 0.049 \\
\hline 33 & 1950 & 0.033 & 0.006 & 0.020 & 0.047 \\
\hline 34 & 1950 & 0.034 & 0.006 & 0.020 & 0.066 \\
\hline 35 & 1950 & 0.035 & 0.005 & 0.020 & 0.051 \\
\hline 36 & 1950 & 0.037 & 0.005 & 0.020 & 0.053 \\
\hline 37 & 1950 & 0.038 & 0.004 & 0.020 & 0.050 \\
\hline 38 & 1950 & 0.040 & 0.004 & 0.022 & 0.052 \\
\hline 39 & 1950 & 0.041 & 0.004 & 0.023 & 0.053 \\
\hline 40 & 1950 & 0.042 & 0.004 & 0.025 & 0.056 \\
\hline 41 & 1950 & 0.042 & 0.005 & 0.028 & 0.057 \\
\hline 42 & 1950 & 0.042 & 0.005 & 0.027 & 0.059 \\
\hline 43 & 1950 & 0.042 & 0.006 & 0.025 & 0.060 \\
\hline 44 & 1950 & 0.042 & 0.006 & 0.026 & 0.056 \\
\hline \multicolumn{6}{|c|}{$\begin{array}{l}\text { Notes: The table shows descriptive statistics of by } \\
\text { age-shares in the female population aged } 15 \text { to } 44 \text { years } \\
\text { (number of observations, mean, standard deviation } \\
\text { minimum, and maximum) on the county level aggre- } \\
\text { gated over all waves used in the estimations. The fig } \\
\text { ures show aggregated values over the years } 1998,2002 \\
2006,2007,2008 \text {, and } 2009 \text {. }\end{array}$} \\
\hline
\end{tabular}


Table A.2: Descriptive statistics of age structure controls II

\begin{tabular}{|c|c|c|c|c|c|}
\hline & $\mathrm{N}$ & Mean & S.D. & Min & Max \\
\hline \multicolumn{6}{|c|}{$\begin{array}{l}\text { Population shares per whole population } \\
\text { by age }\end{array}$} \\
\hline 45 & 1950 & 0.016 & 0.002 & 0.011 & 0.021 \\
\hline 46 & 1950 & 0.016 & 0.002 & 0.011 & 0.021 \\
\hline 47 & 1950 & 0.016 & 0.002 & 0.011 & 0.019 \\
\hline 48 & 1950 & 0.015 & 0.002 & 0.011 & 0.019 \\
\hline 49 & 1950 & 0.015 & 0.001 & 0.011 & 0.019 \\
\hline 50 & 1950 & 0.014 & 0.001 & 0.010 & 0.018 \\
\hline 51 & 1950 & 0.014 & 0.001 & 0.009 & 0.018 \\
\hline 52 & 1950 & 0.013 & 0.002 & 0.008 & 0.018 \\
\hline 53 & 1950 & 0.013 & 0.002 & 0.006 & 0.017 \\
\hline 54 & 1950 & 0.013 & 0.001 & 0.007 & 0.017 \\
\hline 55 & 1950 & 0.013 & 0.001 & 0.008 & 0.017 \\
\hline 56 & 1950 & 0.012 & 0.001 & 0.008 & 0.017 \\
\hline 57 & 1950 & 0.012 & 0.002 & 0.006 & 0.019 \\
\hline 58 & 1950 & 0.0 & 0.002 & 0.007 & 0.019 \\
\hline 59 & 1950 & 0.012 & 0.002 & 0.008 & 0.018 \\
\hline 60 & 1950 & 0. & 0.002 & 0.007 & 0.017 \\
\hline 61 & 1950 & 0. & 0.002 & 0.005 & 0.017 \\
\hline 62 & 1950 & 0. & 0.002 & 0.005 & 0.018 \\
\hline 63 & 1950 & 0. & 0.002 & 0.005 & 0.017 \\
\hline 64 & 1950 & 0. & 0.002 & 0.005 & 0.016 \\
\hline 65 & 1950 & 0. & 0.002 & 0.007 & 0.017 \\
\hline 66 & 1950 & 0.012 & 0.002 & 0.007 & 0.018 \\
\hline 67 & 1950 & 0.012 & 0.002 & 0.007 & 0.017 \\
\hline 68 & 1950 & 0. & 0.002 & 0.007 & .017 \\
\hline 69 & 1950 & 0.0 & 0.002 & 0.006 & 0.017 \\
\hline 70 & 1950 & 0.011 & 0.002 & 0.006 & 0.017 \\
\hline 71 & 1950 & 0.010 & 0.002 & 0.006 & 0.016 \\
\hline 72 & 1950 & 0.010 & 0.001 & 0.006 & 0.014 \\
\hline 73 & 1950 & 0.009 & 0.001 & 0.006 & 0.014 \\
\hline 74 & 1950 & 0.009 & 0.001 & 0.005 & 0.013 \\
\hline $75+$ & 1950 & 0.082 & 0.014 & 0.040 & 0.127 \\
\hline \multicolumn{6}{|c|}{$\begin{array}{l}\text { Notes: The table shows descriptive statistics of by } \\
\text { age-shares shares in the whole population (number } \\
\text { of observations, mean, standard deviation, minimum } \\
\text { and maximum) on the county level aggregated over al } \\
\text { waves used in the estimations. The figures show ag } \\
\text { gregated values over the years } 1998,2002,2006,2007 \\
2008 \text {, and } 2009 \text {. }\end{array}$} \\
\hline
\end{tabular}


Table A.3: Pre-treatment descriptive statistics of age structure controls I

\begin{tabular}{|c|c|c|c|c|c|}
\hline \multirow[t]{2}{*}{ Variable } & \multicolumn{2}{|c|}{ Mean } & \multirow{2}{*}{$\begin{array}{l}\text { Mean-Diff. } \\
\quad(\mathrm{T}-\mathrm{C})\end{array}$} & \multicolumn{2}{|c|}{ T-test } \\
\hline & Control & Treatment & & t-stat & $\mathrm{p}$-value \\
\hline \multicolumn{6}{|c|}{$\begin{array}{l}\text { Female shares per females aged 15-44 } \\
\text { by age }\end{array}$} \\
\hline 15 & 0.0285 & 0.0271 & -0.0013 & 3.2277 & 0.0014 \\
\hline 16 & 0.0282 & 0.0268 & -0.0013 & 3.2546 & 0.0013 \\
\hline 17 & 0.0269 & 0.0257 & -0.0012 & 3.2857 & 0.0011 \\
\hline 18 & 0.0269 & 0.0259 & -0.0010 & 3.1502 & 0.0018 \\
\hline 19 & 0.0274 & 0.0266 & -0.0008 & 3.1925 & 0.0015 \\
\hline 20 & 0.0280 & 0.0281 & 0.0001 & -0.3934 & 0.6943 \\
\hline 21 & 0.0282 & 0.0284 & 0.0002 & -0.4970 & 0.6196 \\
\hline 22 & 0.0285 & 0.0288 & 0.0003 & -0.6557 & 0.5125 \\
\hline 23 & 0.0272 & 0.0274 & 0.0003 & -0.6205 & 0.5354 \\
\hline 24 & 0.0269 & 0.0273 & 0.0005 & -1.0845 & 0.2790 \\
\hline 25 & 0.0269 & 0.0271 & 0.0001 & -0.3569 & 0.7214 \\
\hline 26 & 0.0270 & 0.0272 & 0.0002 & -0.4224 & 0.6730 \\
\hline 27 & 0.0266 & 0.0267 & 0.0001 & -0.2538 & 0.7998 \\
\hline 28 & 0.0274 & 0.0275 & 0.0000 & -0.1460 & 0.8840 \\
\hline 29 & 0.0279 & .0280 & 0.0001 & -0.4957 & 0.6205 \\
\hline 30 & 0.0308 & 0.0308 & -0.0001 & 0.2668 & 0.7898 \\
\hline 31 & 0.0340 & 0.0337 & -0.0003 & 1.3766 & 0.1696 \\
\hline 32 & 0.0356 & 0.0355 & -0.0001 & 0.2474 & 0.8048 \\
\hline 33 & 0.0386 & 0385 & 0.0000 & 0.1648 & 0.8692 \\
\hline 34 & 0.0403 & .0406 & 0.0003 & -0.9018 & 0.3678 \\
\hline 35 & 0.0413 & 0.0416 & 0.0003 & -1.0410 & 0.2987 \\
\hline 36 & 0.0419 & 0.0425 & 0.0007 & -2.1688 & 0.0308 \\
\hline 37 & 0.0417 & 0.0423 & 0.0006 & -1.8915 & 0.0595 \\
\hline 38 & 0.0424 & 0.0432 & 0.0008 & -2.6832 & 0.0077 \\
\hline 39 & 0.0425 & 0.0430 & 0.0005 & -1.8109 & 0.0711 \\
\hline 40 & 0.0413 & 0.0418 & 0.0005 & -1.7008 & 0.0899 \\
\hline 41 & 0.0409 & 0.0416 & 0.0006 & -2.1931 & 0.0290 \\
\hline 42 & 0.0401 & 0.0404 & 0.0003 & -1.1522 & 0.2501 \\
\hline 43 & 0.0390 & 0.0390 & 0.0000 & 0.0158 & 0.9874 \\
\hline 44 & 0.0373 & 0.0371 & -0.0002 & 0.5421 & 0.5881 \\
\hline
\end{tabular}

tests for the control and the treatment group in 2002, the pre-treatment period. The last two columns depict results of T-tests for equality in means for each variable as t-statistics and p-values. Variables are by-age-shares in the female population aged 15 to 44 years. 
Table A.4: Pre-treatment descriptive statistics of age structure controls II

\begin{tabular}{lrrrrr}
\hline Variable & \multicolumn{2}{c}{ Mean } & $\begin{array}{c}\text { Mean-Diff. } \\
\text { (T-C) }\end{array}$ & \multicolumn{2}{c}{ T-test } \\
\multicolumn{7}{c}{ t-stat } & p-value \\
\hline \multicolumn{5}{l}{ Population shares per } \\
by age & whole population \\
45 & 0.0148 & 0.0150 & 0.0002 & -2.7723 & 0.0059 \\
46 & 0.0143 & 0.0146 & 0.0002 & -2.7181 & 0.0069 \\
47 & 0.0138 & 0.0139 & 0.0002 & -2.2761 & 0.0235 \\
48 & 0.0136 & 0.0138 & 0.0002 & -1.9134 & 0.0566 \\
49 & 0.0131 & 0.0133 & 0.0002 & -2.8393 & 0.0048 \\
50 & 0.0132 & 0.0134 & 0.0002 & -2.0668 & 0.0396 \\
51 & 0.0129 & 0.0130 & 0.0001 & -1.1934 & 0.2336 \\
52 & 0.0131 & 0.0133 & 0.0002 & -2.8275 & 0.0050 \\
53 & 0.0129 & 0.0131 & 0.0001 & -1.4717 & 0.1421 \\
54 & 0.0121 & 0.0122 & 0.0001 & -1.0608 & 0.2896 \\
55 & 0.0113 & 0.0114 & 0.0001 & -0.6911 & 0.4900 \\
56 & 0.0103 & 0.0101 & -0.0002 & 1.6863 & 0.0927 \\
57 & 0.0085 & 0.0084 & -0.0001 & 0.7935 & 0.4281 \\
58 & 0.0111 & 0.0111 & 0.0001 & -0.3836 & 0.7015 \\
59 & 0.0113 & 0.0112 & -0.0001 & 0.6151 & 0.5389 \\
60 & 0.0111 & 0.0110 & -0.0002 & 1.2500 & 0.2122 \\
61 & 0.0135 & 0.0135 & 0.0000 & 0.1558 & 0.8763 \\
62 & 0.0144 & 0.0144 & 0.0000 & 0.0903 & 0.9281 \\
63 & 0.0142 & 0.0142 & 0.0000 & 0.1048 & 0.9166 \\
64 & 0.0134 & 0.0132 & -0.0002 & 1.2963 & 0.1958 \\
65 & 0.0125 & 0.0123 & -0.0002 & 1.5472 & 0.1228 \\
66 & 0.0121 & 0.0119 & -0.0002 & 1.1831 & 0.2377 \\
67 & 0.0115 & 0.0113 & -0.0002 & 1.5828 & 0.1145 \\
68 & 0.0107 & 0.0104 & -0.0003 & 2.2030 & 0.0283 \\
69 & 0.0087 & 0.0085 & -0.0002 & 1.9998 & 0.0464 \\
70 & 0.0087 & 0.0085 & -0.0002 & 2.3363 & 0.0201 \\
71 & 0.0087 & 0.0085 & -0.0002 & 2.0768 & 0.0386 \\
72 & 0.0091 & 0.0089 & -0.0003 & 2.6046 & 0.0096 \\
73 & 0.0088 & 0.0086 & -0.0002 & 1.7921 & 0.0740 \\
74 & 0.0086 & 0.0085 & -0.0002 & 1.4854 & 0.1384 \\
$75+$ & 0.0727 & 0.0695 & -0.0032 & 2.1849 & 0.0296 \\
\hline Notes: The table shows means, differences in means and differences-in-means- \\
tests for the control and the treatment group in 2002, the pre-treatment \\
period. The last two columns depict results of T-tests for equality in means \\
for each variable as t-statistics and p-values. Variables are by-age-shares in \\
the whole population. & & & & \\
& & & &
\end{tabular}


Table A.5: Fixed-effects estimates: Effect heterogeneity across age groups

\begin{tabular}{|c|c|c|c|c|c|c|}
\hline & \multicolumn{6}{|c|}{$\begin{array}{l}\text { Birth rate } \\
\qquad t+1\end{array}$} \\
\hline & $\begin{array}{c}\text { aged } 15-19 \\
(1)\end{array}$ & $\begin{array}{l}\text { aged } 20-24 \\
\quad(2)\end{array}$ & $\begin{array}{c}\text { aged } 25-29 \\
(3)\end{array}$ & $\begin{array}{c}\text { aged } 30-34 \\
\quad(4)\end{array}$ & $\begin{array}{c}\text { aged } 35-39 \\
(5)\end{array}$ & $\begin{array}{c}\text { aged } 40-44 \\
\quad(6)\end{array}$ \\
\hline Child care coverage & $\begin{array}{c}7.498^{* * * *} \\
(2.725)\end{array}$ & $\begin{array}{c}12.299^{* *} \\
(6.112)\end{array}$ & $\begin{array}{l}11.167 \\
(8.260)\end{array}$ & $\begin{array}{c}29.032^{* * *} \\
(7.452)\end{array}$ & $\begin{array}{c}10.826^{* *} \\
(4.645)\end{array}$ & $\begin{array}{c}4.819 * * * \\
(1.471)\end{array}$ \\
\hline Regional controls & Yes & Yes & Yes & Yes & Yes & Yes \\
\hline Year FE & Yes & Yes & Yes & Yes & Yes & Yes \\
\hline County FE & Yes & Yes & Yes & Yes & Yes & Yes \\
\hline $\begin{array}{l}\text { Percent effect of 10pp } \\
\text { childcare increase }\end{array}$ & 0.077 & 0.027 & 0.012 & 0.033 & 0.027 & 0.073 \\
\hline $\begin{array}{l}\text { Number of } \\
\text { additional children }\end{array}$ & 1,340 & 2,278 & 2,206 & 6,181 & 2,675 & 1,291 \\
\hline $\mathrm{N}$ & 1,950 & 1,950 & 1,950 & 1,950 & 1,950 & 1,950 \\
\hline Number of counties & 325 & 325 & 325 & 325 & 325 & 325 \\
\hline F-statistic & 56.25 & 85.23 & 32.24 & 23.48 & 95.21 & 42.30 \\
\hline
\end{tabular}

Notes: The table shows the results of county fixed-effects estimations. The outcome variables are age group specific birth rates, i.e., births of women within the corresponding age group per 1,000 women aged 15-19 (column 1), 20-24 (column 2), 25-29 (column 3), 30-34 (column 4), 35-39 (column 5), and 40-44 (column 6). All outcome variable are forwarded by one period. Regional control variables include the county's population density, GDP per capita, the male employment rate, the interpolated conservative vote share as well as an extensive set of age structure controls. Age structure control variables include the year-of-age share of 15 to 44 year old women over all women aged 15 to 44 and the year-of-age shares of 45 to 74 year old and 75 plus years old people over the population in each county. The number of additional children from a 10pp increase in child care coverage is computed as the effect of a 10pp increase in child care on birth rates multiplied by the average number of females in the respective age bracket multiplied by the number of counties in the sample. Robust standard errors are clustered at the county level and given in parentheses. ${ }^{* * *} 1$ percent significance level; ** 5 percent significance level; * 10 percent significance level. 
Figure A.1: Child care coverage in selected counties over time

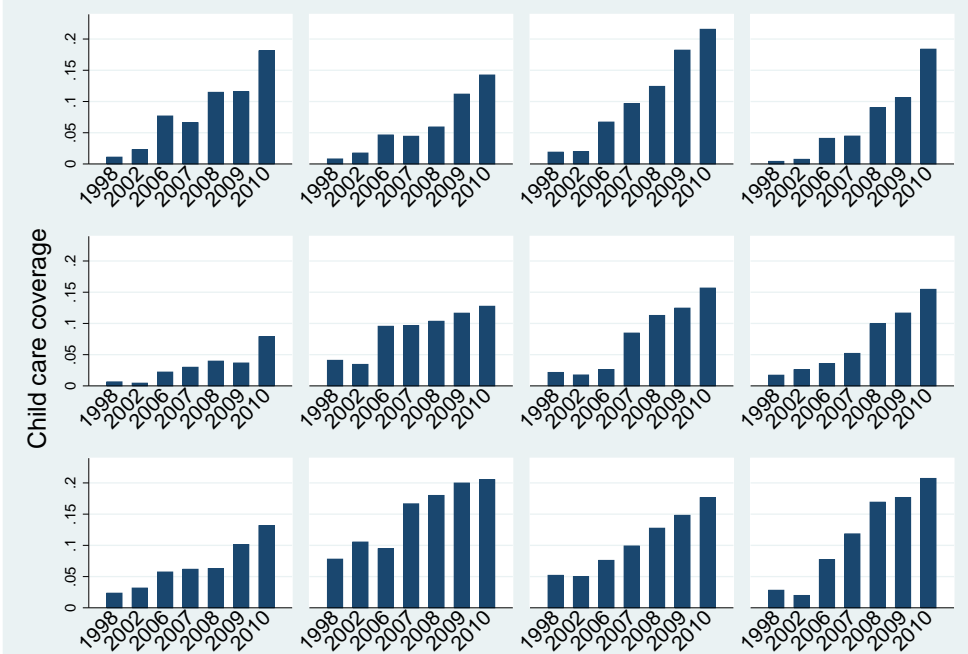

Notes: The figure shows child care coverage over time for individual, selected counties. Each panel depicts a single county. 
Figure A.2: Changes in child care coverage in selected counties over time

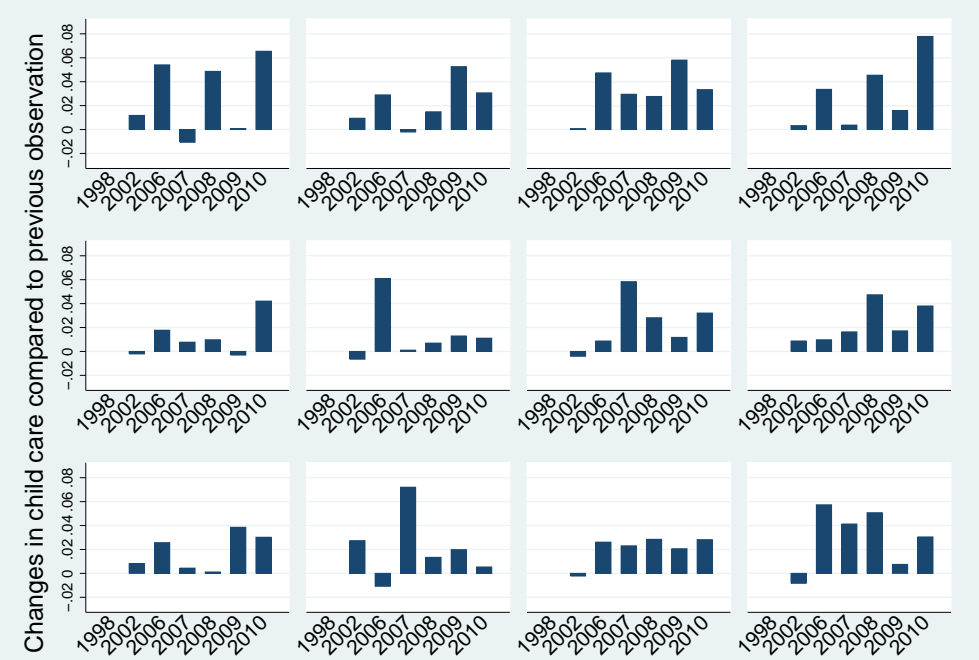

Notes: The figure shows changes in child care coverage over time relative to the previous observation for individual, selected counties. Each panel depicts a single county. 


\section{B. Data Appendix}

County level data from the Statistical Offices of the German Länder (Statistische Landesämter) is provided in per year per item files. We identify counties by official id numbers and conduct a county level panel from 1997 to 2010. During this investigation period, reforms in geographic local government competency and in data aggregation rules altered county identifiers in some instances. In order to get a fully balanced panel, we made necessary changes that produced time-stable units of observations. Hannover, Aachen and Saarbruecken are merged to city-urban regions, whereas in earlier waves each consists of two separate counties. We use the merged definition throughout all waves and add up values if necessary. Our basic data is from the Statistical Offices of the German Länder (Statistische Landesämter), whereas the employment related data is from the Federal Employment Agency and matched using county-year identifiers.

Our variables have different underlying measurement concepts. Child care slots, population and employment are record date measures, reported in the first half of March (child care from 2006 onwards), 31st December (population, child care until 2002) resp. 30th June (employment). Births, GDP and in- and out-migrants are yearly sums. Births per 1,000 women are defined as the sum of births within the year divided by population as of 31st December. As child care from 2006 onwards is evaluated in March and population on 31st December, we divide it by one year lagged population. Child care in 1998 and 2002 is measured on 31st December and is therefore divided by population in the same year.

Public child care figures are conducted from two different data collections by the Statistical Offices of the German Länder (Statistische Landesämter). Public child care is defined as all publicly funded or subsidized child care, including child care centers and childminders. From 2006 onwards we observe occupied child care slots, whereas in 1998 and 2002 we observe available child care slots. As there was excess demand for child care, we can credibly assume both measures to be comparable. However, there is reason to believe that in 1998 and 2002 the number of public child care slots is underestimated. In these years, children under the age of three that were enrolled in child care centers for over three year olds are not included in the supply measures and the number of childminders had be estimated. The undervaluation of public child care coverage is believed to be of the magnitude of about one percentage point (DJI, 2008). 